\title{
LEVEL II SCOUR ANALYSIS FOR BRIDGE 39 (STOWTH00160039) on TOWN HIGHWAY 16, crossing MOSS GLEN BROOK, STOWE, VERMONT
}

Open-File Report 97-794

Prepared in cooperation with

VERMONT AGENCY OF TRANSPORTATION

and

FEDERAL HIGHWAY ADMINISTRATION

\section{U.S. Department of the Interior}

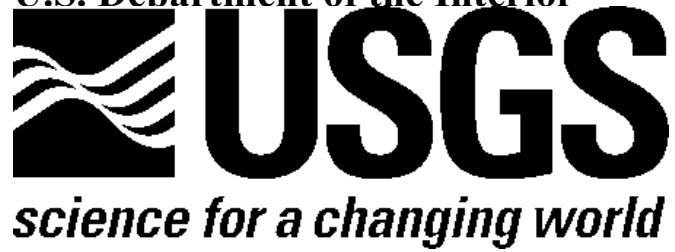




\section{LEVEL II SCOUR ANALYSIS FOR BRIDGE 39 (STOWTH00160039) on TOWN HIGHWAY 16, crossing MOSS GLEN BROOK, STOWE, VERMONT}

By MICHAEL A. IVANOFF AND ROBERT E. HAMMOND

U.S. Geological Survey Open-File Report 97-794

Prepared in cooperation with

VERMONT AGENCY OF TRANSPORTATION and

FEDERAL HIGHWAY ADMINISTRATION 


\title{
U.S. DEPARTMENT OF THE INTERIOR BRUCE BABBITT, Secretary
}

\author{
U.S. GEOLOGICAL SURVEY \\ Mark Schaefer, Acting Director
}

For additional information write to:

District Chief

U.S. Geological Survey 361 Commerce Way

Pembroke, NH 03275-3718
Copies of this report may be purchased from:

U.S. Geological Survey

Branch of Information Services

Open-File Reports Unit

Box 25286

Denver, CO 80225-0286 


\section{CONTENTS}

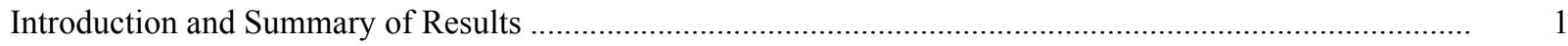

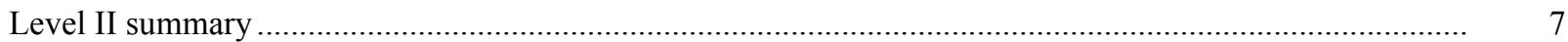

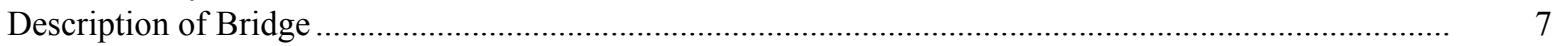

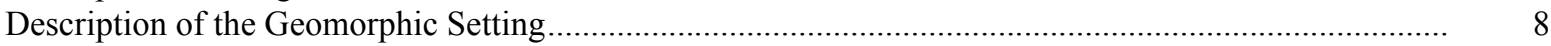

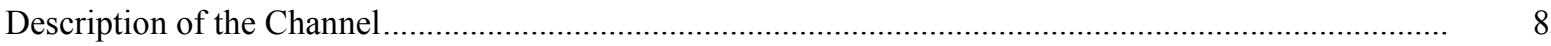

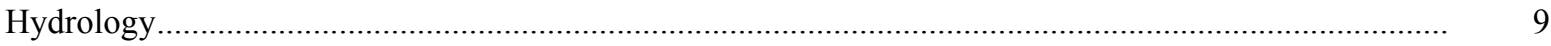

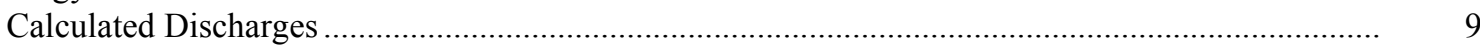

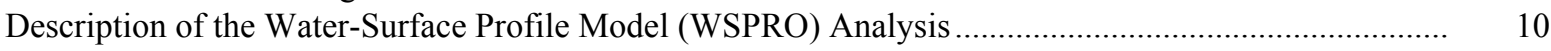

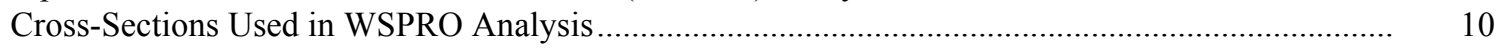

Data and Assumptions Used in WSPRO Model ...................................................................... 11

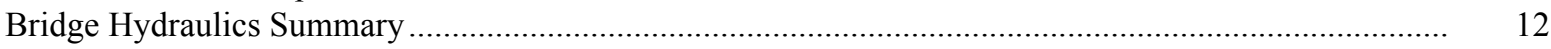

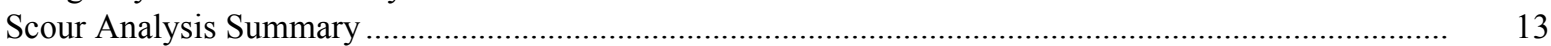

Special Conditions or Assumptions Made in Scour Analysis ...................................................... 13

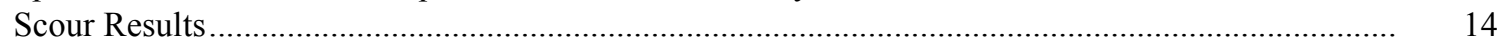

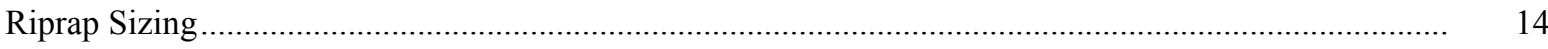

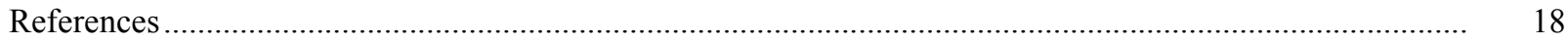

Appendixes:

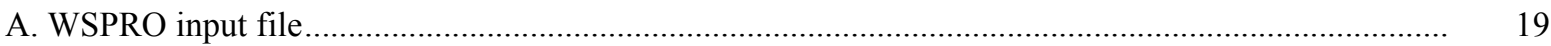

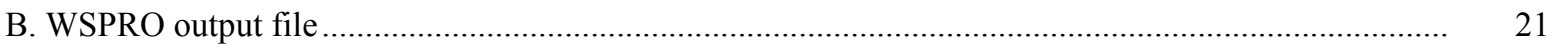

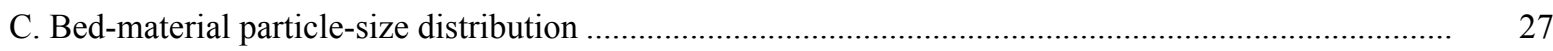

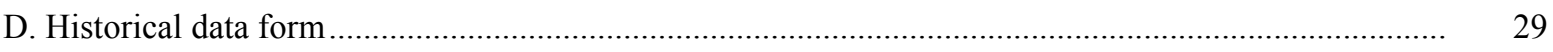

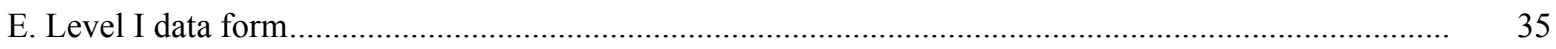

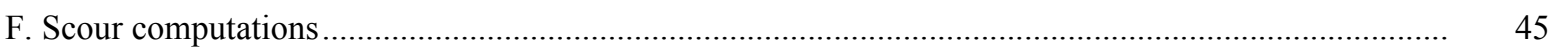

\section{FIGURES}

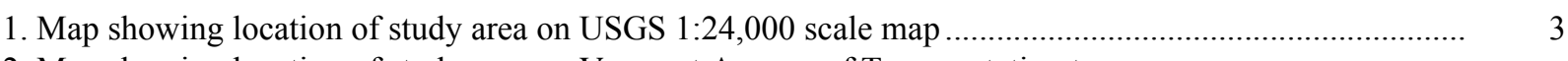

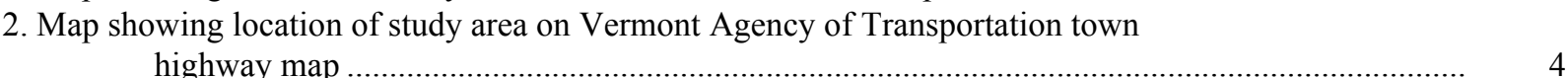

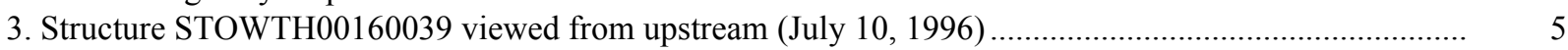

4. Downstream channel viewed from structure STOWTH00160039 (July 10, 1996). ............................... 5

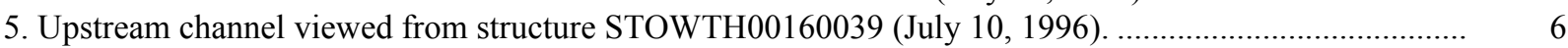

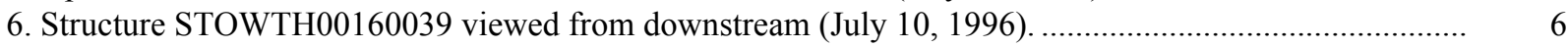

7. Water-surface profiles for the 100- and 500-year discharges at structure

STOWTH00160039 on Town Highway 16, crossing Moss Glen Brook,

Stowe, Vermont.

8. Scour elevations for the 100- and 500-year discharges at structure

STOWTH00160039 on Town Highway 16, crossing Moss Glen Brook,

Stowe, Vermont.

\section{TABLES}

1. Remaining footing/pile depth at abutments for the 100-year discharge at structure

STOWTH00160039 on Town Highway 16, crossing Moss Glen Brook,

Stowe, Vermont

2. Remaining footing/pile depth at abutments for the 500-year discharge at structure

STOWTH00160039 on Town Highway 16, crossing Moss Glen Brook,

Stowe, Vermont

5
(1) 


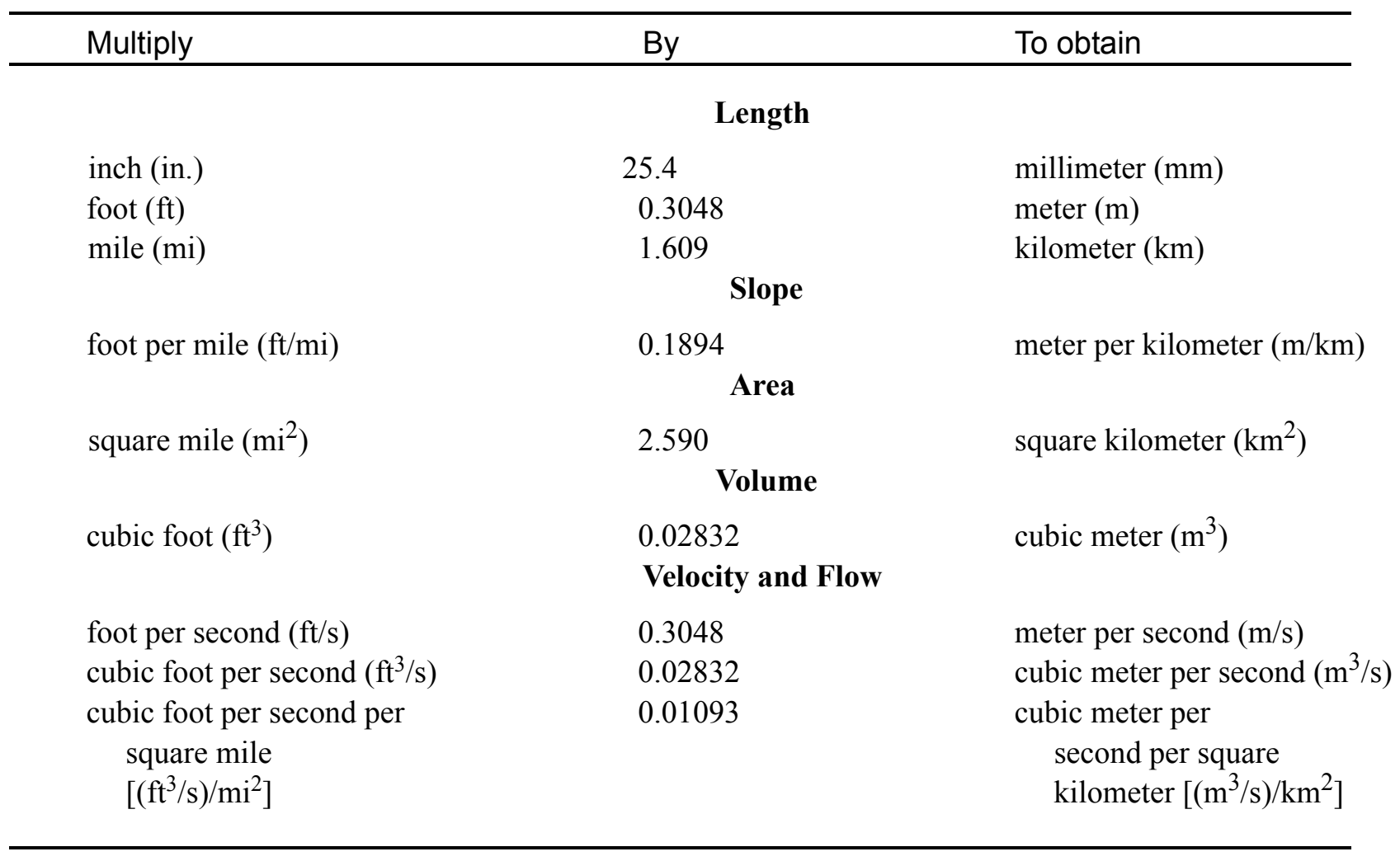

\section{OTHER ABBREVIATIONS}

$\begin{array}{lrlr}\mathrm{BF} & \text { bank full } & \text { LWW } & \text { left wingwall } \\ \mathrm{cfs} & \text { cubic feet per second } & \text { MC } & \text { main channel } \\ \mathrm{D}_{50} & \text { median diameter of bed material } & \text { RAB } & \text { right abutment } \\ \mathrm{DS} & \text { downstream } & \text { RABUT } & \text { face of right abutment } \\ \mathrm{elev} & \text { elevation } & \text { RB } & \text { right bank } \\ \mathrm{f} / \mathrm{p} & \text { flood plain } & \text { ROB } & \text { right overbank } \\ \mathrm{ft}^{2} & \text { square feet } & \text { RWW } & \text { right wingwall } \\ \mathrm{ft} / \mathrm{ft} & \text { feet per foot } & \text { TH } & \text { town highway } \\ \mathrm{JCT} & \text { junction } & \text { UB } & \text { under bridge } \\ \mathrm{LAB} & \text { left abutment } & \text { US } & \text { upstream } \\ \mathrm{LABUT} & \text { face of left abutment } & \text { USGS } & \text { United States Geological Survey } \\ \mathrm{LB} & \text { left bank } & \text { VTAOT Vermont Agency of Transportation } \\ \mathrm{LOB} & \text { left overbank } & \text { WSPRO } & \text { water-surface profile model }\end{array}$

In this report, the words "right" and "left" refer to directions that would be reported by an observer facing downstream. Sea level: In this report, "sea level" refers to the National Geodetic Vertical Datum of 1929-- a geodetic datum derived from a general adjustment of the first-order level nets of the United States and Canada, formerly called Sea Level Datum of 1929.

In the appendices, the above abbreviations may be combined. For example, USLB would represent upstream left bank. 


\title{
LEVEL II SCOUR ANALYSIS FOR BRIDGE 39 (STOWTH00160039) ON TOWN HIGHWAY 16, CROSSING MOSS GLEN BROOK, STOWE, VERMONT
}

\author{
By Michael A. Ivanoff and Robert E. Hammond
}

\section{INTRODUCTION AND SUMMARY OF RESULTS}

This report provides the results of a detailed Level II analysis of scour potential at structure STOWTH00160039 on Town Highway 16 crossing Moss Glen Brook, Stowe, Vermont (figures 1-8). A Level II study is a basic engineering analysis of the site, including a quantitative analysis of stream stability and scour (U.S. Department of Transportation, 1993). Results of a Level I scour investigation also are included in Appendix E of this report. A Level I investigation provides a qualitative geomorphic characterization of the study site. Information on the bridge, gleaned from Vermont Agency of Transportation (VTAOT) files, was compiled prior to conducting Level I and Level II analyses and is found in Appendix D.

The site is in the Green Mountain section of the New England physiographic province in north-central Vermont. The $4.75-\mathrm{mi}^{2}$ drainage area is in a predominantly rural and forested basin. In the vicinity of the study site, the surface cover is forest upstream and on the right bank downstream. The downstream left bank is pasture while the immediate bank has dense woody vegetation.

In the study area, Moss Glen Brook has an incised, sinuous channel with a slope of approximately $0.02 \mathrm{ft} / \mathrm{ft}$, an average channel top width of $52 \mathrm{ft}$ and an average bank height of $7 \mathrm{ft}$. The channel bed material ranges from sand to cobble with a median grain size $\left(\mathrm{D}_{50}\right)$ of $56.5 \mathrm{~mm}(0.185 \mathrm{ft})$. The geomorphic assessment at the time of the Level I and Level II site visit on July 10, 1996, indicated that the reach was stable.

The Town Highway 16 crossing of Moss Glen Brook is a 22-ft-long galvanized plate arch culvert with an opening span width of $21 \mathrm{ft}$ (Vermont Agency of Transportation, written communication, October 13, 1995). The opening length of the structure parallel to the culvert face is $20.6 \mathrm{ft}$. The culvert is supported by vertical, concrete abutments with no wingwalls. The channel is skewed approximately zero degrees to the opening. The opening skew-to-roadway value from the VTAOT database is 5 degrees while zero degrees was computed from surveyed points. 
The only scour counter measure at the site was type- 3 stone fill (less than 48 inches diameter) at the upstream and downstream ends of the left and right abutments and extending along the banks upstream and downstream. Additional details describing conditions at the site are included in the Level II Summary and Appendices D and E.

Scour depths and recommended rock rip-rap sizes were computed using the general guidelines described in Hydraulic Engineering Circular 18 (Richardson and others, 1995) for the 100- and 500-year discharges. Total scour at a highway crossing is comprised of three components: 1) long-term streambed degradation; 2) contraction scour (due to accelerated flow caused by a reduction in flow area at a bridge) and; 3 ) local scour (caused by accelerated flow around piers and abutments). Total scour is the sum of the three components. Equations are available to compute depths for contraction and local scour and a summary of the results of these computations follows.

Contraction scour for all modelled flows ranged from 0.0 to $1.2 \mathrm{ft}$. The worst-case contraction scour occurred at the 500-year discharge. Left abutment scour ranged from 12.6 to $16.2 \mathrm{ft}$. Right abutment scour ranged from 12.1 to $14.3 \mathrm{ft}$. The worst-case abutment scour occurred at the 500-year discharge. Additional information on scour depths and depths to armoring are included in the section titled "Scour Results". Scoured-streambed elevations, based on the calculated scour depths, are presented in tables 1 and 2. A cross-section of the scour computed at the bridge is presented in figure 8. Scour depths were calculated assuming an infinite depth of erosive material and a homogeneous particle-size distribution.

It is generally accepted that the Froehlich equation (abutment scour) gives "excessively conservative estimates of scour depths" (Richardson and others, 1995, p. 47). Usually, computed scour depths are evaluated in combination with other information including (but not limited to) historical performance during flood events, the geomorphic stability assessment, existing scour protection measures, and the results of the hydraulic analyses. Therefore, scour depths adopted by VTAOT may differ from the computed values documented herein. 


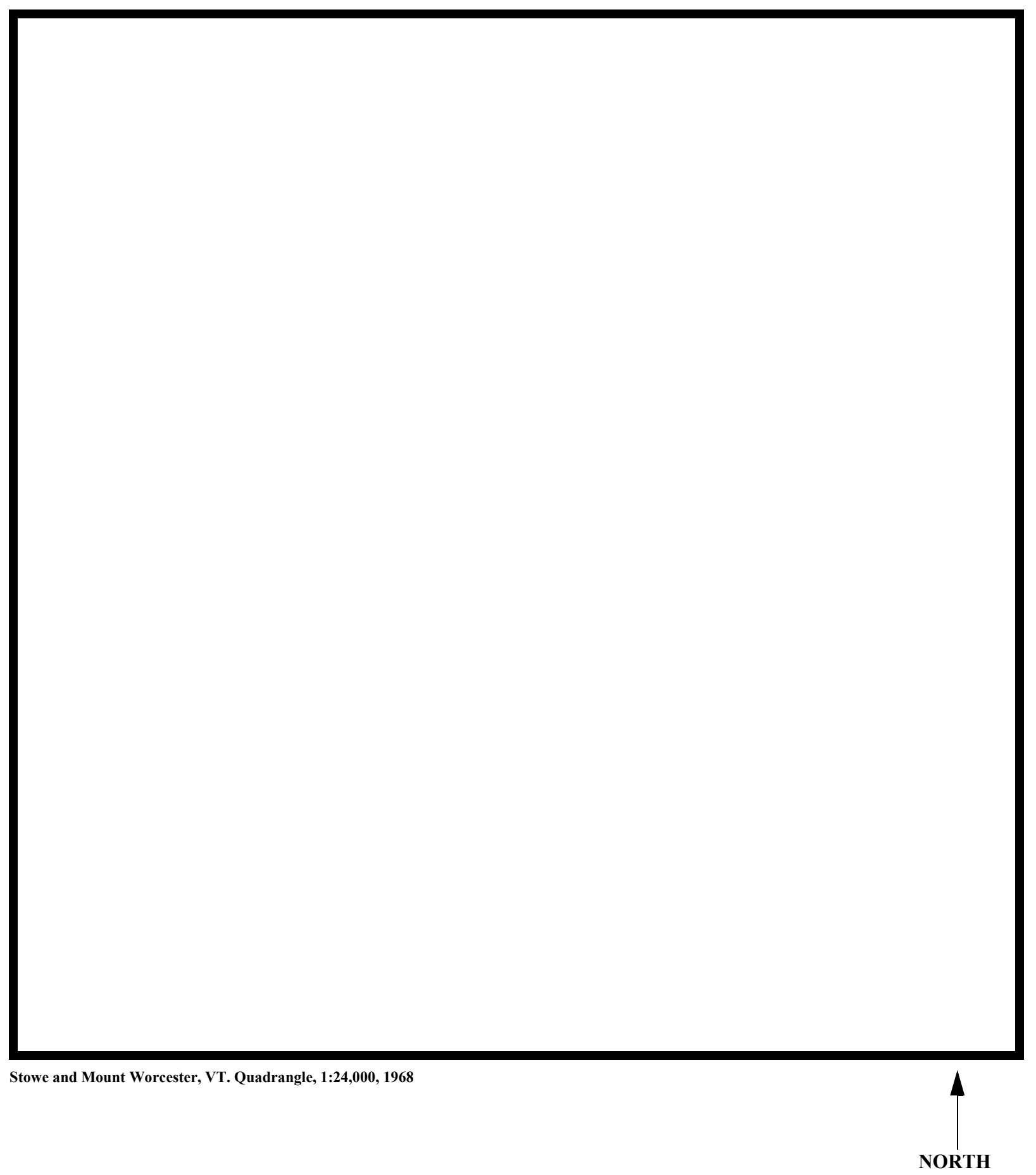

Figure 1. Location of study area on USGS 1:24,000 scale map. 
Figure 2. Location of study area on Vermont Agency of Transportation town highway map. 

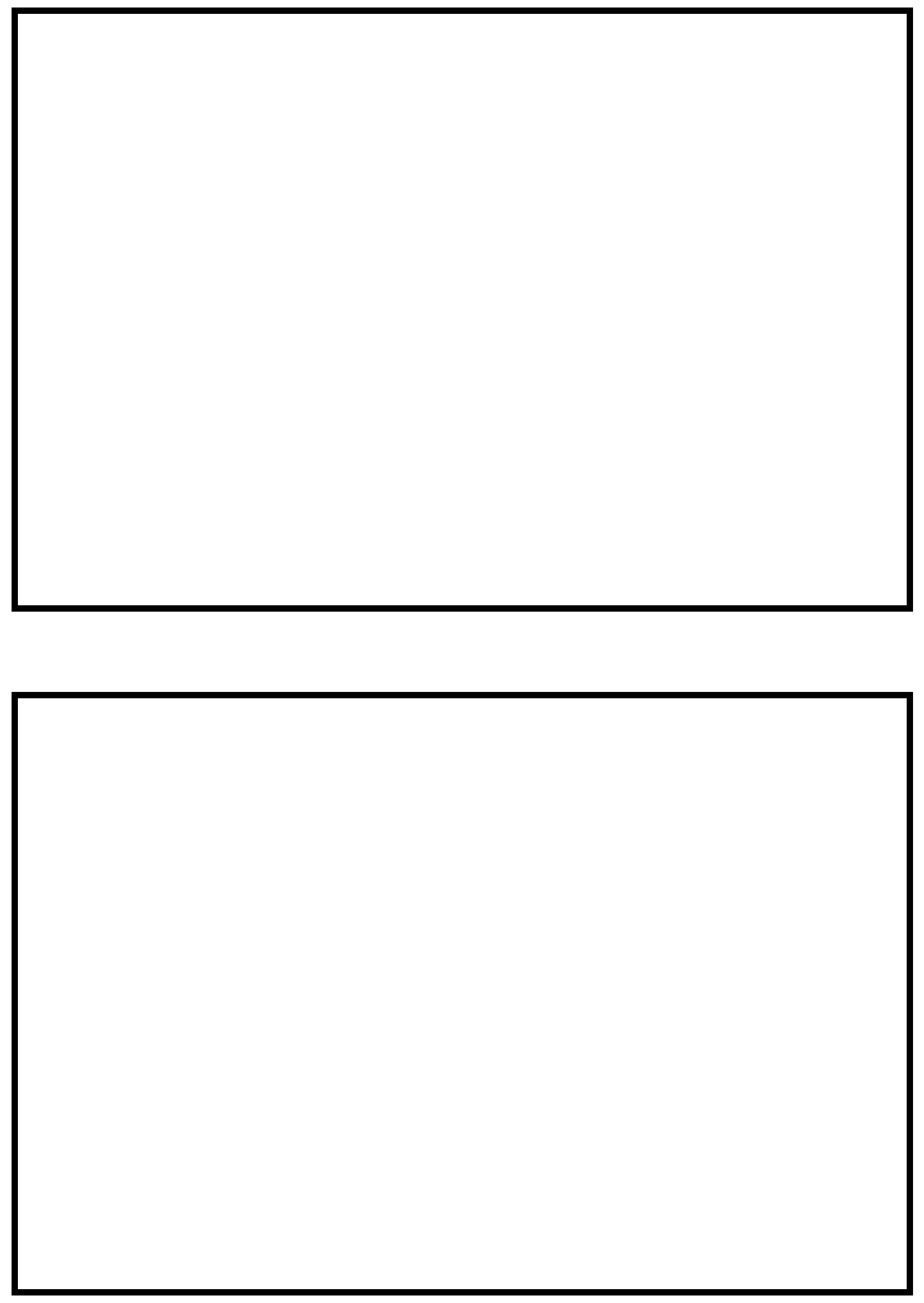

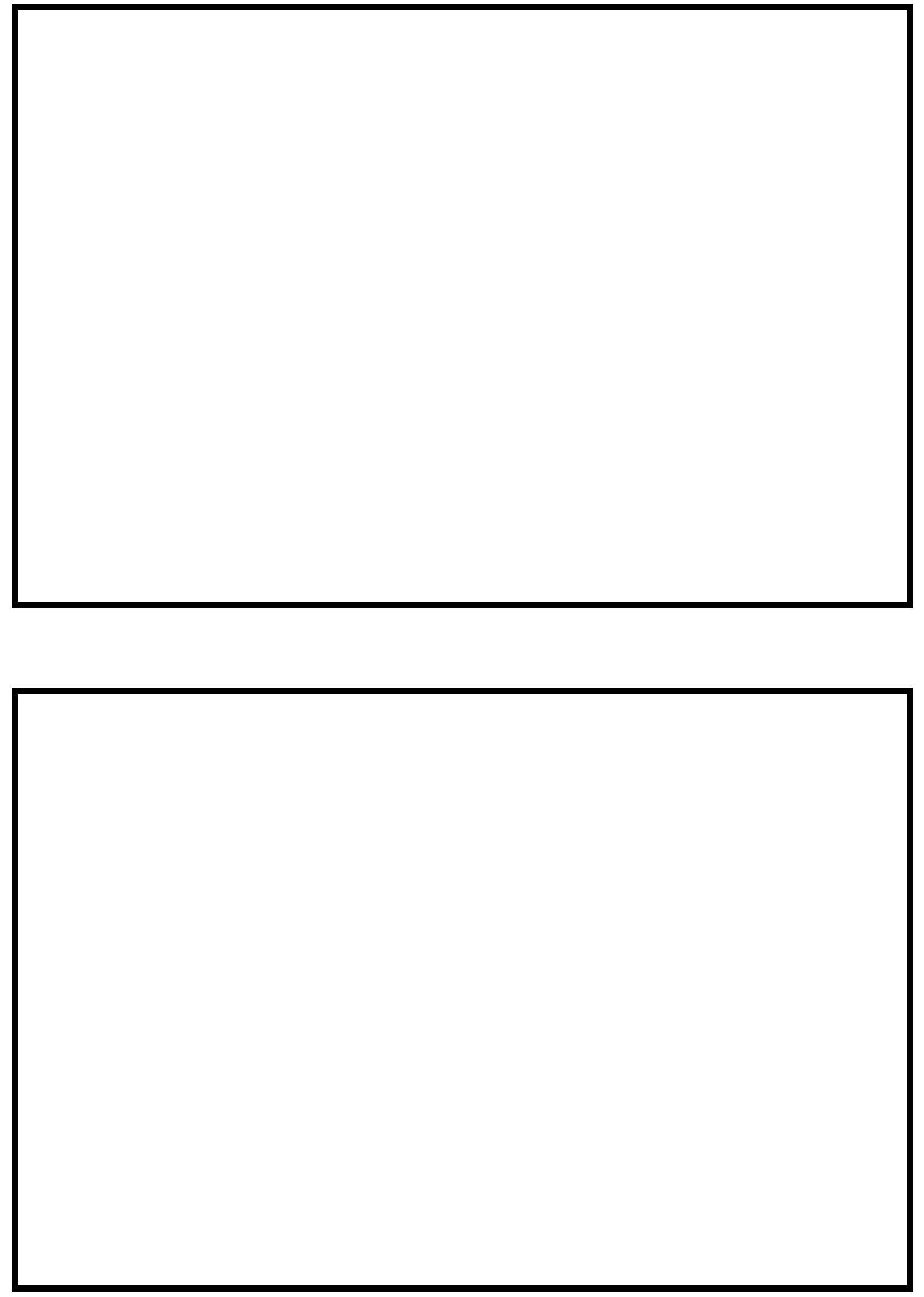


\section{LEVEL II SUMMARY}

\begin{tabular}{llllll} 
Structure Number & \multicolumn{2}{c}{ STOWTH00160039 } & Stream & \multicolumn{2}{c}{ Moss Glen Brook } \\
& Lounty & Lamoille & TH 16 & District & 6
\end{tabular}

\section{Description of Bridge}

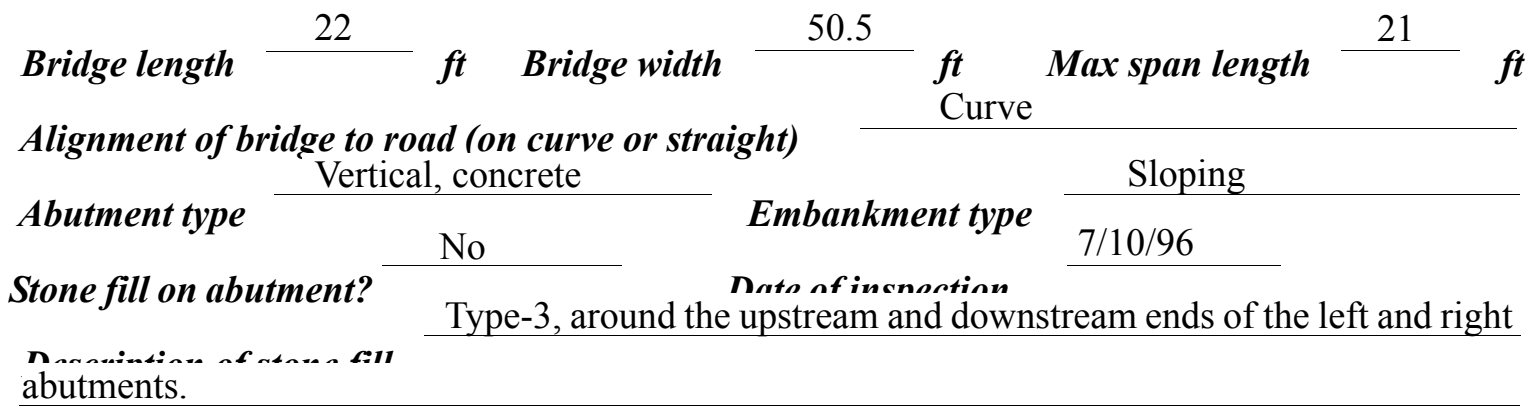

Abutments are concrete. The concrete abutments are supporting a corrugated galvanized plate pipe arch.

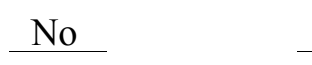

Is bridge skewed to flood flow according to Yes 'survey? Angle

There is a moderate channel bend in the upstream reach.

Debris accumulation on bridge at time of Level I or Level II site visit:

\begin{tabular}{|c|c|c|c|}
\hline & $\begin{array}{c}\text { Date of insnortion } \\
7 / 10 / 96 \\
\end{array}$ & $\begin{array}{l}\text { Percent of rham } 0 \text { al } \\
\text { blocked inortzontatly }\end{array}$ & $\begin{array}{l}\text { Percent of } 0 \\
\text { blocked verticatty }\end{array}$ \\
\hline Level I & $7 / 10 / 96$ & 0 & 0 \\
\hline
\end{tabular}

Level II

High. There is debris caught on concrete blocks along the upstream

left bank and trees leaning over the channel upstream.

Potential for debris

None as of 7/10/96.

Doscriho any, foaturos noar ar at tho hridos that mav, affoct flou, (includo ahsorvation dato) 


\section{Description of the Geomorphic Setting}

General topography The channel is located within a moderate relief valley with narrow flood plains and steep valley walls on both sides.

Geomorphic conditions at bridge site: downstream (DS), upstream (US)

Date of inspection $\quad 7 / 10 / 96$

DS left: $\quad$ Steep channel bank to a narrow flood plain.

DS right: $\quad$ Steep channel bank to a narrow flood plain.

US left: $\quad$ Moderately sloped channel bank to a narrow flood plain.

US right: $\quad$ Steep channel bank to a narrow flood plain.

\section{Description of the Channel}

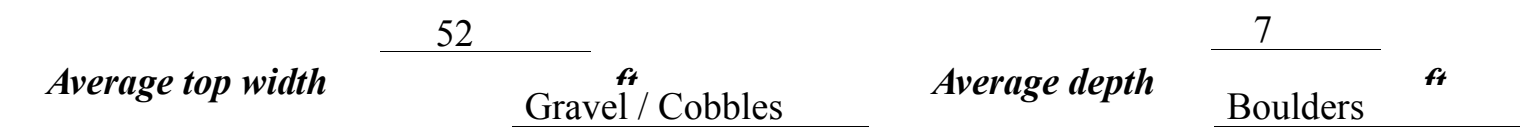

Predominant bed material

Bank material Sinuous but stable

with non-alluvial channel boundaries and a narrow flood plain.

$7 / 10 / 96$

Vegetative co 1 Trees and brush with cut grass on the overbank.

DS left: $\quad$ Trees and brush.

DS right: $\quad$ Trees and brush.

US left: $\quad$ Trees and brush.

US right: $\quad$ Yes

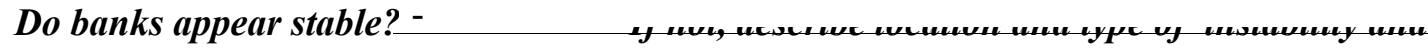

date of observation.

None, $7 / 10 / 96$.

Describe any obstructions in channel and date of observation. 


\title{
Hydrology
}

Drainage area $\frac{4.75}{m i^{2}}$

Percentage of drainage area in physiographic provinces: (approximate)

Physiographic province/section

New England/Green Mountain
Percent of drainage area 100

\begin{abstract}
Is drainage area considered rural or urban? Rural _ Describe any significant urbanization:
\end{abstract}

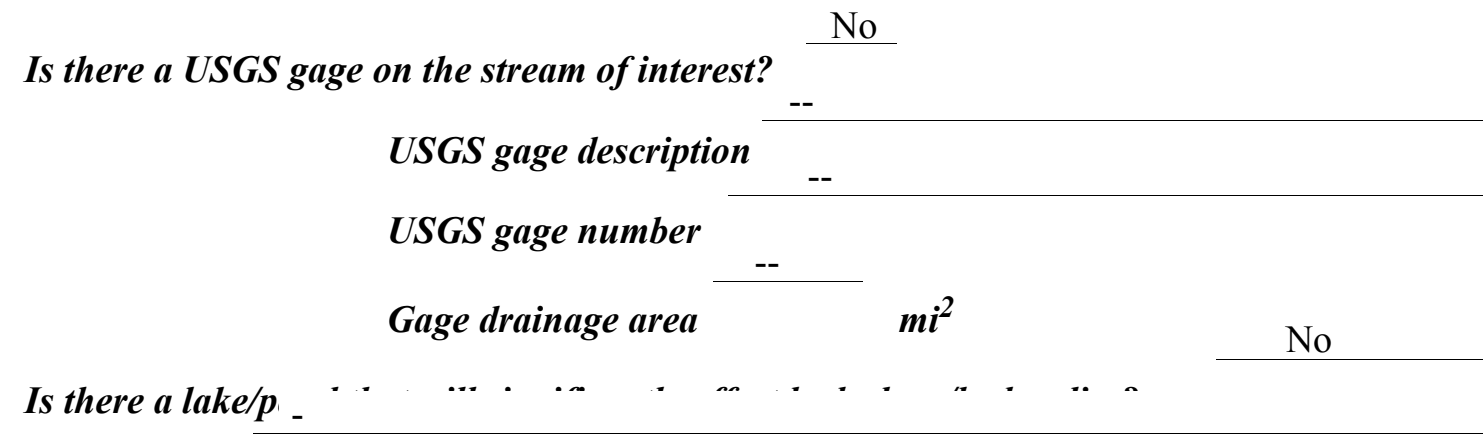

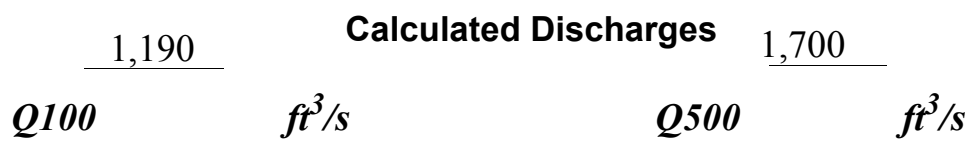

The 100- and 500-year discharges are based on the

flood frequency estimates for this site available from the VTAOT database. The drainage area above bridge number 39 in the VTAOT database is 4.57 square miles. The discharge values are within a range defined by several empirical flood frequency curves (Benson, 1962; Johnson and Tasker, 1974; FHWA, 1983; Potter, 1957a\&b; Talbot, 1887). 


\section{Description of the Water-Surface Profile Model (WSPRO) Analysis}

Datum for WSPRO analysis (USGS survey, sea level, VTAOT plans)

USGS survey

Datum tie between USGS survey and VTAOT plans

None

Description of reference marks used to determine USGS datum. $\quad$ RM1 is a nail $6 \mathrm{ft}$ high

in a telephone pole by the edge of TH 16 on the right bank in line with the road over the culvert

(elev. $502.62 \mathrm{ft}$, arbitrary survey datum). RM2 is a bolt on the top left center of the downstream

end of the culvert (elev. $496.61 \mathrm{ft}$, arbitrary survey datum). RM3 is a bolt on the top right center

on the upstream end of the culvert (elev. $496.21 \mathrm{ft}$, arbitrary

survey datum).

\begin{tabular}{cccl}
\hline${ }^{1}$ Cross-section & $\begin{array}{c}\text { Section } \\
\text { Reference } \\
\text { Distance } \\
(\text { SRD) } \text { in feet }\end{array}$ & $\begin{array}{c}{ }^{2} \text { Cross-section } \\
\text { development }\end{array}$ & \multicolumn{1}{c}{ Comments } \\
\hline EXITX & -22 & 1 & Exit section \\
FULLV & 0 & 2 & $\begin{array}{l}\text { Downstream Full-valley } \\
\text { section (Templated from } \\
\text { EXITX) }\end{array}$ \\
APPRO & 75 & 1 & Approach section \\
\hline
\end{tabular}

${ }^{1}$ For location of cross-sections see plan-view sketch included with Level I field form, Appendix E.

For more detail on how cross-sections were developed see WSPRO input file.

2 Cross-section development: (1) survey at SRD, (2) shift of survey data to SRD, (3) modification of survey data,

(4) composite bridge section, (5) other. 


\section{Data and Assumptions Used in WSPRO Model}

Hydraulic analyses of the reach were done by use of the Federal Highway Administration's WSPRO step-backwater computer program (Shearman and others, 1986, and Shearman, 1990). The analyses reported herein reflect conditions existing at the site at the time of the study. Furthermore, in the development of the model it was necessary to assume no accumulation of debris or ice at the site. Results of the hydraulic model are presented in the Bridge Hydraulic Summary, Appendix B, and figure 7.

Channel roughness factors (Manning's " $n$ ") used in the hydraulic model were estimated using field inspections at each cross section following the general guidelines described by Arcement and Schneider (1989). Final adjustments to the values were made during the modelling of the reach. Channel " $\mathrm{n}$ " values for the reach ranged from 0.035 to 0.070 , and overbank " $n$ " values ranged from 0.040 to 0.055 .

Normal depth at the exit section (EXITX) was assumed as the starting water surface. This depth was computed by use of the slope-conveyance method outlined in the user's manual for WSPRO (Shearman, 1990). The slope used was $0.0153 \mathrm{ft} / \mathrm{ft}$, which was estimated from surveyed thalweg points downstream of the culvert.

The approach section (APPRO) was surveyed one culvert width upstream of the upstream face as recommended by Shearman and others (1986). This location provides a consistent method for determining scour variables.

The unconstricted channel was modeled for each discharge by use of WSPRO. Then the water surface elevation computed at the full valley section (FULLV) for each discharge under the unconstricted channel condition was applied as the starting water surface elevation for modeling the culvert hydraulics for each discharge. 


\section{Bridge Hydraulics Summary}

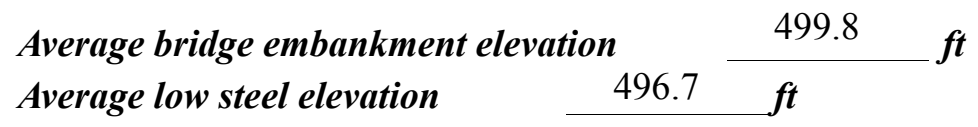

$$
\text { 100-year discharge } \quad 1,190 \quad \mathrm{ft}^{3} / \mathrm{s}
$$

Water-surface elevation in bridge opening $\quad 492.1 \quad f t$

Road overtopping? ___ No Discharge over road ___-- $\mathrm{ft}^{3} / \mathrm{s}$

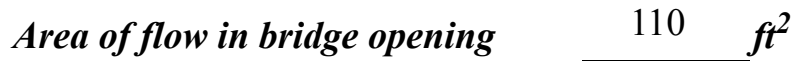

Average velocity in bridge opening $10.8 \mathrm{ft} / \mathrm{s}$

Maximum WSPRO tube velocity at bridge $\quad--\quad \mathrm{ft} / \mathrm{s}$

Water-surface elevation at Approach section with bridge 495.4

Water-surface elevation at Approach section without bridge $\quad 493.3$

Amount of backwater caused by bridge $\quad 2.1 \quad$ it

500-year discharge $\quad 1,700 \quad \mathrm{ft}^{3} / \mathrm{s}$

Water-surface elevation in bridge opening $\quad 493.1 \mathrm{ft}$

Road overtopping? ___ No Discharge over road __ -- . $3 / 5$

Area of flow in bridge opening $\quad 126 \quad \mathrm{ft}^{2}$

Average velocity in bridge opening $13.5 \mathrm{ft} / \mathrm{s}$

Maximum WSPRO tube velocity at bridge $\quad-{ }_{-} \quad$ 's

Water-surface elevation at Approach section with bridge $\quad 498.0$

Water-surface elevation at Approach section without bridge $\quad 494.3$

Amount of backwater caused by bridge $\quad 3.7, t$

Incipient overtopping discharge ___ -- $\mathrm{ft}^{3} / \mathrm{s}$

Water-surface elevation in bridge opening $\quad--\quad t$

Area of flow in bridge opening _ -- $\mathrm{ft}^{2}$

Average velocity in bridge opening __-- $\mathrm{ft} / \mathrm{s}$

Maximum WSPRO tube velocity at bridge _-- $\mathrm{ft} / \mathrm{s}$

Water-surface elevation at Approach section with bridge

Water-surface elevation at Approach section without bridge

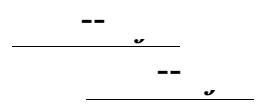

Amount of backwater caused by bridge _ 


\section{Scour Analysis Summary}

\section{Special Conditions or Assumptions Made in Scour Analysis}

Scour depths were computed using the general guidelines described in Hydraulic Engineering Circular 18 (Richardson and others, 1995). Scour depths were calculated assuming an infinite depth of erosive material and a homogeneous particle-size distribution. The results of the scour analysis are presented in tables 1 and 2 and a graph of the scour depths is presented in figure 8 .

Contraction scour for the 100-year and 500-year discharges were computed by use of the Laursen clear-water contraction scour equation (Richardson and others, 1995, p. 32, equation 20). The streambed armoring depths computed suggest that armoring will not limit the depth of contraction scour.

Abutment scour was computed by use of the Froehlich equation (Richardson and others, 1995, p. 48, equation 28). Variables for the Froehlich equation include the Froude number of the flow approaching the embankments, the length of the embankment blocking flow, and the depth of flow approaching the embankment less any roadway overtopping. 


\section{Scour Results}

\section{0-yr discharge 500-yr discharge}

Contraction scour:

(Scour depths in feet)

Main channel

Live-bed scour

Clear-water scour

Depth to armoring

Left overbank

Right overbank

Local scour:

Abutment scour

Left abutment

12.6

16.2

$12.1-$

$14.3-$

Right abutment

Pier scour

Pier 1

Pier 2

Pier 3

\section{Abutments:}

Left abutment

Right abutment

Piers:

Pier 1

Pier 2

Incipient overtopping discharge 


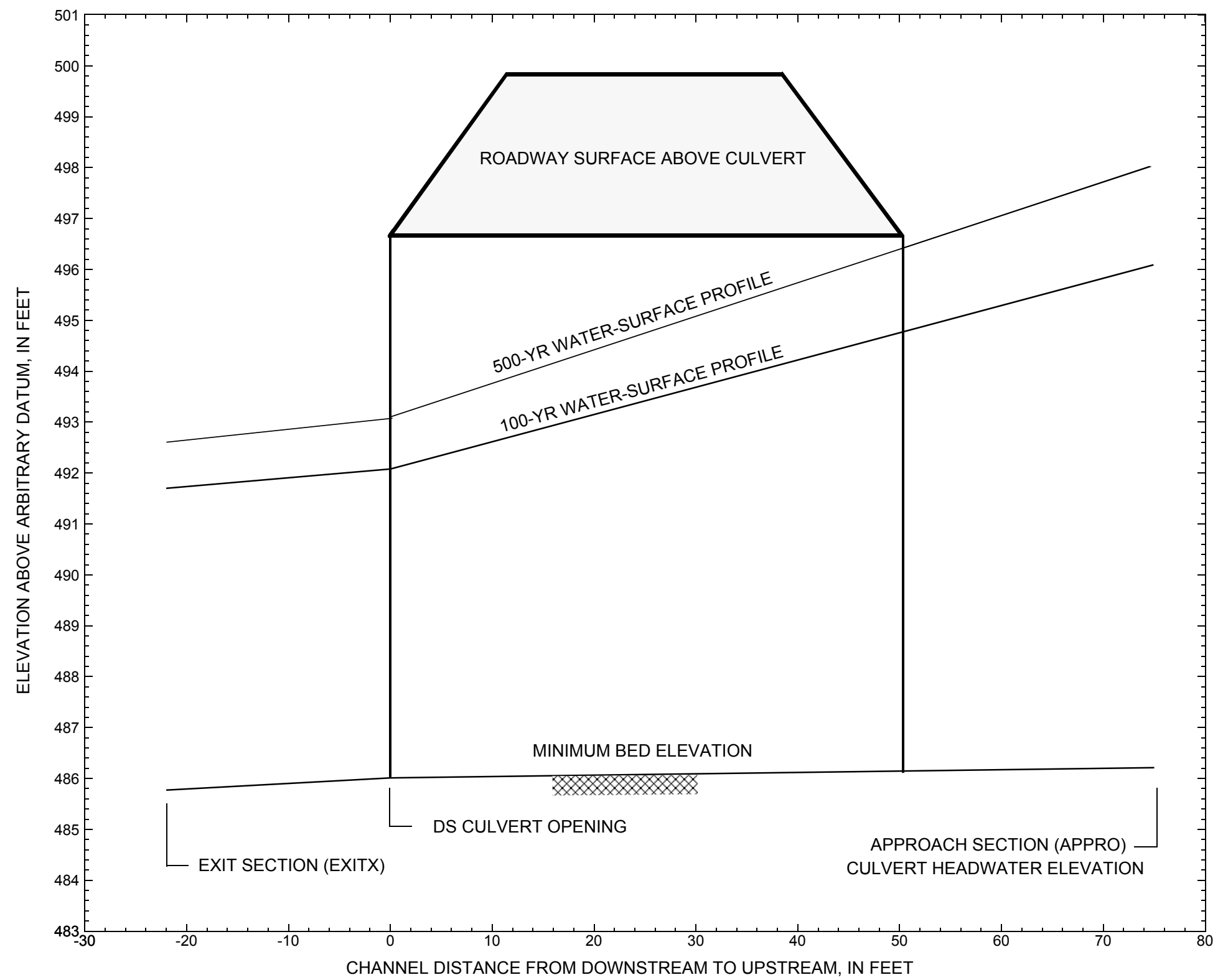

Figure 7. Water-surface profiles for the 100- and 500-yr discharges at structure STOWTH00160039 on Town Highway 16, crossing Moss Glen Brook, Stowe, Vermont. 


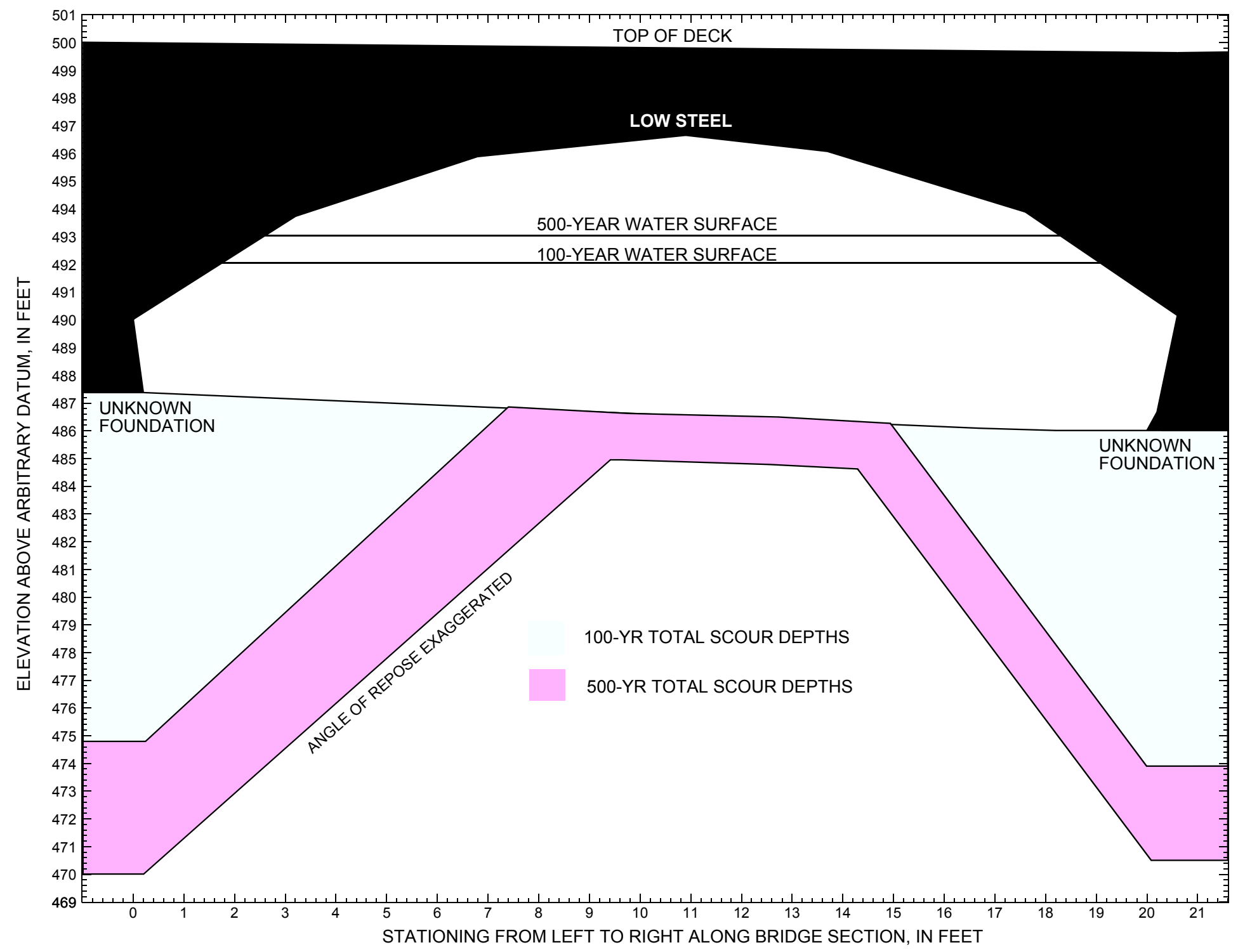

Figure 8. Scour elevations for the 100-yr and 500-yr discharges at structure STOWTH00160039 on Town Highway 16, crossing Moss Glen Brook, Stowe, Vermont. 
Table 1. Remaining footing/pile depth at abutments for the 100-year discharge at structure STOWTH00160039 on Town Highway 16, crossing Moss Glen Brook, Stowe, Vermont.

[VTAOT, Vermont Agency of Transportation; --,no data]

\begin{tabular}{|c|c|c|c|c|c|c|c|c|c|c|c|}
\hline Description & Station $^{1}$ & $\begin{array}{l}\text { VTAOT } \\
\text { minimum } \\
\text { low-chord } \\
\text { elevation } \\
\text { (feet) }\end{array}$ & $\begin{array}{l}\text { Surveyed } \\
\text { minimum } \\
\text { low-chord } \\
\text { elevation }{ }^{2} \\
\text { (feet) }\end{array}$ & $\begin{array}{c}\text { Bottom of } \\
\text { footing/pile } \\
\text { elevation }{ }^{2} \\
\text { (feet) }\end{array}$ & $\begin{array}{l}\text { Channel } \\
\text { elevation at } \\
\text { abutment/ } \\
\text { pier }{ }^{2} \\
\text { (feet) }\end{array}$ & $\begin{array}{l}\text { Contraction } \\
\text { scour depth } \\
\text { (feet) }\end{array}$ & $\begin{array}{l}\text { Abutment } \\
\text { scour } \\
\text { depth } \\
\text { (feet) }\end{array}$ & $\begin{array}{l}\text { Pier } \\
\text { scour } \\
\text { depth } \\
\text { (feet) }\end{array}$ & $\begin{array}{l}\text { Depth of } \\
\text { total scour } \\
\text { (feet) }\end{array}$ & $\begin{array}{c}\text { Elevation of } \\
\text { scour }^{2} \\
\text { (feet) }\end{array}$ & $\begin{array}{c}\text { Remaining } \\
\text { footing/pile } \\
\text { depth } \\
\text { (feet) }\end{array}$ \\
\hline \multicolumn{12}{|c|}{ 100-yr. discharge is 1,190 cubic-feet per second } \\
\hline Left abutment & 0.0 & -- & 496.7 & -- & 487.4 & 0.0 & 12.6 & -- & 12.6 & 474.8 & -- \\
\hline Right abutment & 20.6 & -- & 496.7 & -- & 486.0 & 0.0 & 12.1 & -- & 12.1 & 473.9 & -- \\
\hline
\end{tabular}

1.Measured along the face of the most constricting side of the bridge.

2.Arbitrary datum for this study.

Table 2. Remaining footing/pile depth at abutments for the 500-year discharge at structure STOWTH00160039 on Town Highway 16, crossing Moss Glen Brook, Stowe, Vermont.

[VTAOT, Vermont Agency of Transportation; --, no data]

\begin{tabular}{|c|c|c|c|c|c|c|c|c|c|c|c|}
\hline Description & Station $^{1}$ & $\begin{array}{l}\text { VTAOT } \\
\text { minimum } \\
\text { low-chord } \\
\text { elevation } \\
\text { (feet) }\end{array}$ & $\begin{array}{c}\text { Surveyed } \\
\text { minimum } \\
\text { low-chord } \\
\text { elevation } \\
\text { (feet) }\end{array}$ & $\begin{array}{c}\text { Bottom of } \\
\text { footing/pile } \\
\text { elevation } \\
\text { (feet) }\end{array}$ & $\begin{array}{c}\text { Channel } \\
\text { elevation at } \\
\text { abutment/ } \\
\text { pier }^{2} \\
\text { (feet) }\end{array}$ & $\begin{array}{l}\text { Contraction } \\
\text { scour depth } \\
\text { (feet) }\end{array}$ & $\begin{array}{c}\text { Abutment } \\
\text { scour } \\
\text { depth } \\
\text { (feet) }\end{array}$ & $\begin{array}{l}\text { Pier } \\
\text { scour } \\
\text { depth } \\
\text { (feet) }\end{array}$ & $\begin{array}{l}\text { Depth of } \\
\text { total scour } \\
\text { (feet) }\end{array}$ & $\begin{array}{c}\text { Elevation of } \\
\text { scour }^{2} \\
\text { (feet) }\end{array}$ & $\begin{array}{c}\text { Remaining } \\
\text { footing/pile } \\
\text { depth } \\
\text { (feet) }\end{array}$ \\
\hline \multicolumn{12}{|c|}{500 -yr. discharge is 1,700 cubic-feet per second } \\
\hline Left abutment & 0.0 & -- & 496.7 & -- & 487.4 & 1.2 & 16.2 & -- & 17.4 & 470.0 & -- \\
\hline Right abutment & 20.6 & -- & 496.7 & -- & 486.0 & 1.2 & 14.3 & -- & 15.5 & 470.5 & -- \\
\hline
\end{tabular}

1.Measured along the face of the most constricting side of the bridge.

2.Arbitrary datum for this study. 


\section{SELECTED REFERENCES}

Arcement, G.J., Jr., and Schneider, V.R., 1989, Guide for selecting Manning's roughness coefficients for natural channels and flood plains: U.S. Geological Survey Water-Supply Paper 2339, 38 p.

Barnes, H.H., Jr., 1967, Roughness characteristics of natural channels: U.S. Geological Survey Water-Supply Paper 1849,213 p.

Benson, M. A., 1962, Factors Influencing the Occurrence of Floods in a Humid Region of Diverse Terrain: U.S. Geological Survey WaterSupply Paper 1580-B, 64 p.

Brown, S.A. and Clyde, E.S., 1989, Design of riprap revetment: Federal Highway Administration Hydraulic Engineering Circular No. 11, Publication FHWA-IP-89-016, 156 p.

Federal Highway Administration, 1983, Runoff estimates for small watersheds and development of sound design: Federal Highway Administration Report FHWA-RD-77-158.

Federal Highway Administration, 1993, Stream Stability and Scour at Highway Bridges: Participant Workbook: Federal Highway Administration Report FHWA-HI-91-011.

Froehlich, D.C., 1989, Local scour at bridge abutments in Ports, M.A., ed., Hydraulic Engineering--Proceedings of the 1989 National Conference on Hydraulic Engineering: New York, American Society of Civil Engineers, p. 13-18.

Hayes, D.C.,1993, Site selection and collection of bridge-scour data in Delaware, Maryland, and Virginia: U.S. Geological Survey WaterResources Investigation Report 93-4017, 23 p.

Interagency Advisory Committee on Water Data, 1982, Guidelines for determining flood flow frequency: U.S. Geological Survey, Bulletin 17B of the Hydrology Subcommittee, 190 p.

Johnson, C.G. and Tasker, G.D.,1974, Progress report on flood magnitude and frequency of Vermont streams: U.S. Geological Survey OpenFile Report 74-130, 37 p.

Lagasse, P.F., Schall, J.D., Johnson, F., Richardson, E.V., Chang, F., 1995, Stream Stability at Highway Structures: Federal Highway Administration Hydraulic Engineering Circular No. 20, Publication FHWA-IP-90-014, 144 p.

Laursen, E.M., 1960, Scour at bridge crossings: Journal of the Hydraulics Division, American Society of Civil Engineers, v. 86, no. HY2, p. 39-53.

Potter, W. D., 1957a, Peak rates of runoff in the Adirondack, White Mountains, and Maine woods area, Bureau of Public Roads

Potter, W. D., 1957b, Peak rates of runoff in the New England Hill and Lowland area, Bureau of Public Roads

Richardson, E.V. and Davis, S.R., 1995, Evaluating scour at bridges: Federal Highway Administration Hydraulic Engineering Circular No. 18, Publication FHWA-IP-90-017, 204 p.

Richardson, E.V., Simons, D.B., and Julien, P.Y., 1990, Highways in the river environment: Federal Highway Administration Publication FHWA-HI-90-016.

Ritter, D.F., 1984, Process Geomorphology: W.C. Brown Co., Debuque, Iowa, 603 p.

Shearman, J.O., 1990, User's manual for WSPRO--a computer model for water surface profile computations: Federal Highway Administration Publication FHWA-IP-89-027, 187 p.

Shearman, J.O., Kirby, W.H., Schneider, V.R., and Flippo, H.N., 1986, Bridge waterways analysis model; research report: Federal Highway Administration Publication FHWA-RD-86-108, 112 p.

Talbot, A.N., 1887, The determination of water-way for bridges and culverts.

U.S. Department of Transportation, 1993, Stream stability and scour at highway bridges, Participant Workbook: Federal Highway Administration Publication FHWA HI-91-011.

U.S. Geological Survey, 1968, Mount Worcester, Vermont 7.5 Minute Series quadrangle map: U.S. Geological Survey Topographic Maps, Scale 1:24,000.

U.S. Geological Survey, 1968, Stowe, Vermont 7.5 Minute Series quadrangle map: U.S. Geological Survey Topographic Maps, Scale 1:24,000. 


\section{APPENDIX A: \\ WSPRO INPUT FILE}




\section{WSPRO INPUT FILE}

GR

GR

GR

GR

GR

$\mathrm{N}$

SA

XS

XS

GR

GR

GR

GR

GR

GR

*

$\mathrm{N}$

SA

*

HP 1 APPRO $495.37 \quad 1 \quad 495.37$

HP 2 APPRO 495.37 * * 1190

*

HP 1 APPRO 498.011498 .01

HP 2 APPRO $498.01 * * 1700$

*

$\mathrm{EX}$

$\mathrm{ER}$

\section{Culvert Analysis}

T1

$\mathrm{T} 2$

*

Q

WS

*

$\begin{array}{llllllll} & \mathrm{CV} & \text { CULVT } & 0 & 11 & 50 & 486.01 & 486.02\end{array}$

$\begin{array}{llll}C G & 327 & 128 & 251\end{array}$
$-182.1, \quad 501.52$

$-8.7,491.73$

$8.1,486.06$

$21.9,486.48$

$62.3,498.01$

$-145.5,494.82$

$0.0,489.63$

$11.5,486.07$

$28.5,489.45$

$80.2,497.93$

0.045

38.2

0.0109

$$
-135.7,501.56
$$

$-73.4,499.98$

$-46.0,497.70$

$-11.3,491.23$

$-4.5,490.39$

$10.1,486.27$

$26.5,488.30$

$96.3,498.61$

$-77.1,494.18$

$5.2,486.64$

$15.1,485.77$

$38.2,495.96$

$114.5,499.41$

EX

ER 


\section{APPENDIX B: \\ WSPRO OUTPUT FILE}


U.S. Geological Survey WSPRO Input File stow039.wsp

Hydraulic analysis for structure STOWTH00160039 Date: 15-AUG-97 Arch Culvert 39 on Town Highway 16 over Moss Glen Brook Stowe, VT MAI

*** RUN DATE \& TIME: 11-06-97 15:22

\begin{tabular}{|c|c|c|c|c|c|c|c|c|c|c|c|}
\hline & CROSS-SEC & ETION & PROPER & RTIES: & ISEQ & $2=3$ & $\mathrm{SECI}$ & $I D=A P P R O$ & SRD & $=$ & 75. \\
\hline & WSEL & SA\# & AREA & & K & TOPW & WETE & $\mathrm{ALPH}$ & LEW & REW & \\
\hline & & 1 & 101 & & 5656 & 33 & 34 & & & & \\
\hline & & 2 & 294 & & 21780 & 42 & 45 & & & & \\
\hline & 495.37 & & 395 & & 27436 & 76 & 79 & 1.04 & -37 & 38 & \\
\hline & VELOCITY & DISTR & RIBUTIC & $\mathrm{DN}$ : & $\mathrm{ISEQ}=$ & $3 ;$ & SECID $=$ & $=\mathrm{APPRO} ;$ & $\mathrm{SRD}=$ & & 75. \\
\hline & WSEL & & LEW & REW & $\mathrm{AR}$ & EA & $\mathrm{K}$ & $Q$ & VEL & & \\
\hline & 495.37 & & 37.9 & 37.7 & 395 & .1 & 27436 . & 1190. & 3.01 & & \\
\hline $\mathrm{x}$ & STA. & -37.9 & & -21.3 & & -14.5 & & -9.2 & -5.0 & & -1.3 \\
\hline & $A(I)$ & & 33.3 & & 23.7 & & 21.7 & 19.9 & & 21.6 & \\
\hline & $V(I)$ & & 1.78 & & 2.52 & & 2.74 & 2.98 & & 2.76 & \\
\hline $\mathrm{X}$ & STA. & -1.3 & & 1.1 & & 3.1 & & 5.0 & 6.8 & & 8.4 \\
\hline & $A(I)$ & & 18.2 & & 16.4 & & 16.4 & 15.8 & & 15.2 & \\
\hline & $V(I)$ & & 3.27 & & 3.63 & & 3.63 & 3.77 & & 3.91 & \\
\hline $\mathrm{X}$ & STA. & 8.4 & & 10.2 & & 11.9 & & 13.7 & 15.6 & & 17.5 \\
\hline & $A(I)$ & & 15.7 & & 15.6 & & 16.1 & 16.7 & & 16.6 & \\
\hline & $V(I)$ & & 3.78 & & 3.82 & & 3.70 & 3.57 & & 3.58 & \\
\hline $\mathrm{x}$ & STA. & 17.5 & & 19.6 & & 21.7 & & 24.3 & 27.4 & & 37.7 \\
\hline & $A(I)$ & & 17.6 & & 18.1 & & 19.9 & 22.3 & & 34.3 & \\
\hline & $\mathrm{V}(\mathrm{I})$ & & 3.39 & & 3.28 & & 2.99 & 2.67 & & 1.73 & \\
\hline
\end{tabular}

\begin{tabular}{|c|c|c|c|c|c|c|c|c|c|c|}
\hline CROSS- & SECTION & PROPER & & ISEQ & $=3 ;$ & SECID & $=\mathrm{APE}$ & $\mathrm{SF}$ & $=$ & 75. \\
\hline \multirow[t]{3}{*}{ WSEL } & SA\# & AREA & & K & TOPW & WETP & $\mathrm{ALPH}$ & LEW & REW & QCR \\
\hline & 1 & 202 & & 616 & 45 & 46 & & & & 2415 \\
\hline & 2 & 411 & & 5530 & 46 & 50 & & & & 6956 \\
\hline 498.01 & & 612 & & 145 & 91 & 96 & 1.02 & -49 & 42 & 8913 \\
\hline
\end{tabular}

VELOCITY DISTRIBUTION: ISEQ $=3 ;$ SECID $=$ APPRO; $\quad$ SRD $=75$.

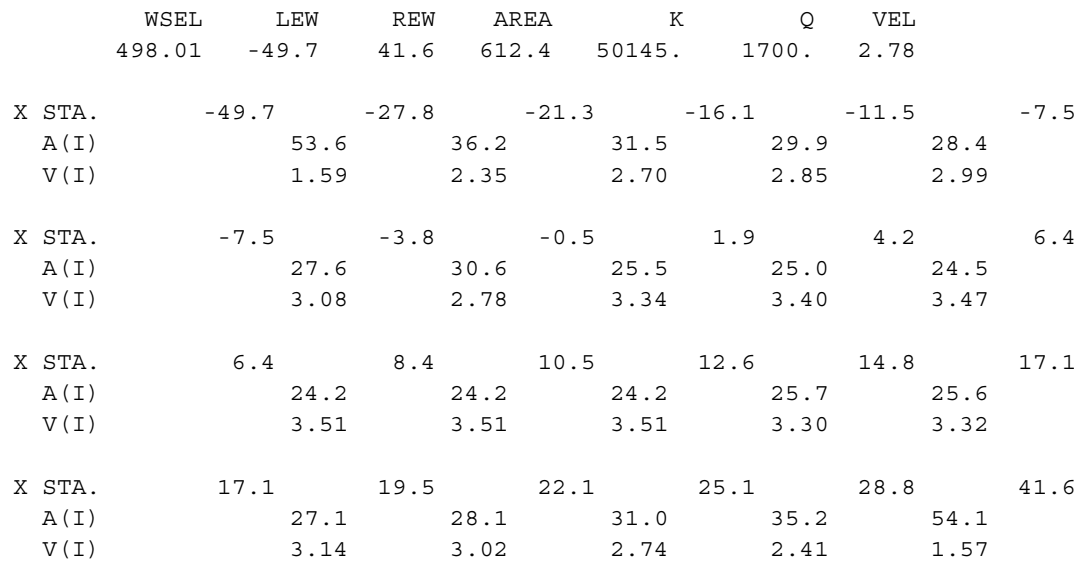




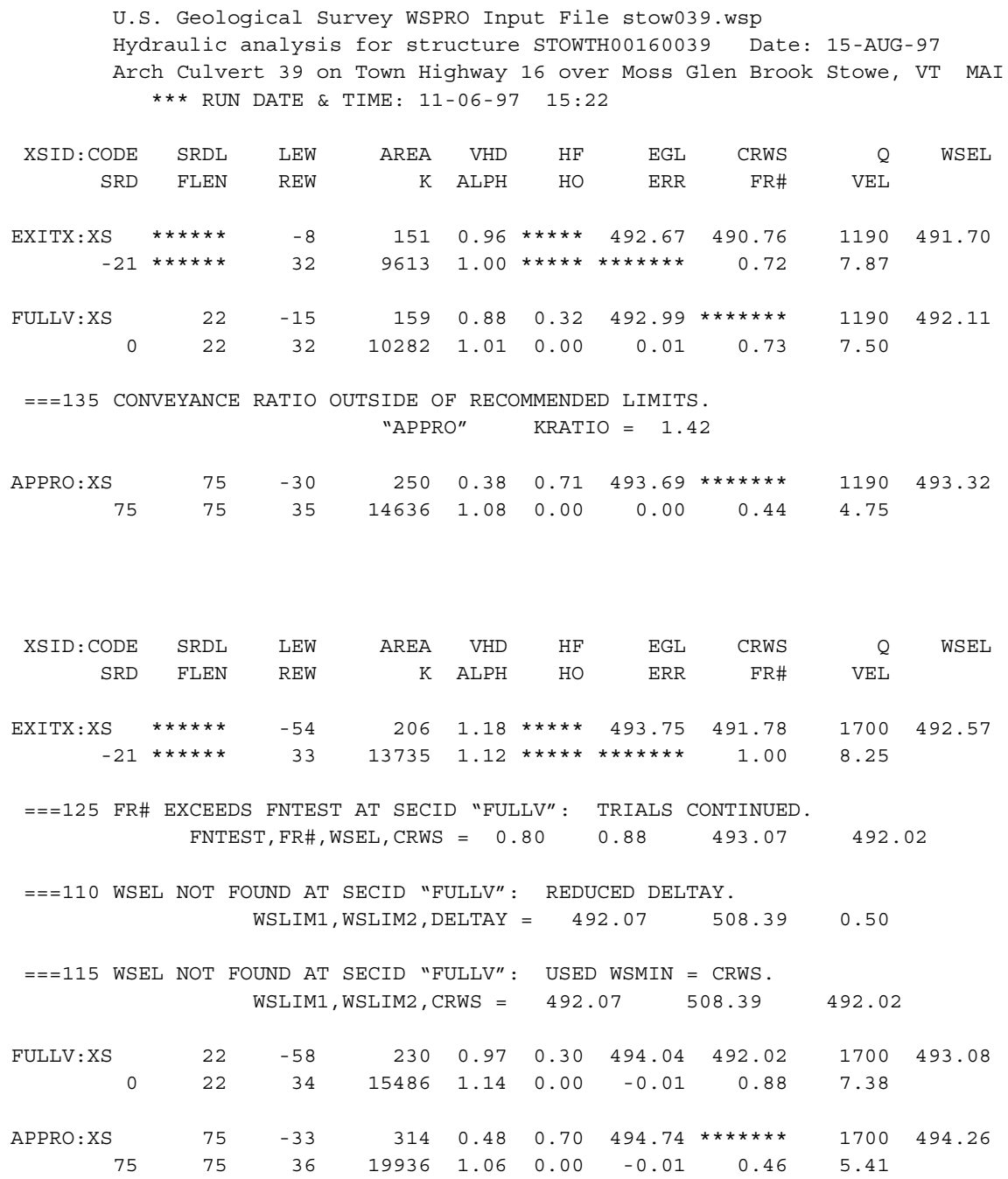

Culvert bridge \# 39 on Moss Glen Brook in Stowe, VT STOWTH00160039

*** RUN DATE \& TIME: 11-21-97 07:55 CULVERT SUMMARY :

$\begin{array}{rrrrrr}\text { ISHAPE } & \text { RISE } & \text { SPAN } & \text { BOTRAD } & \text { TOPRAD } & \text { CORNER } \\ 3 & 128.00 & 251.00 & 434.38 & 125.59 & 18.00 \\ \text { IEQNO } & \text { CKE } & \text { CN } & \text { CVALPH } & \text { CVLENG } & \text { CVSLPE } \\ 12 & 0.50 & 0.035 & 1.16 & 50.00 & 0.0002 \\ & & & & & \\ \text { TWDEP } & \text { QBBL } & \text { HWIC } & \text { HWOC } & \text { OTFULL } & \\ 6.10 & 1190.00 & 8.33 & 9.36 & -2.36 & \\ \text { DSUBC } & \text { ASUBC } & \text { DSUBN } & \text { ASUBN } & & \\ 5.38 & 97.53 & 10.67 & 165.76 & & \\ & & & & & \\ \text { VELOT } & \text { AOUT } & \text { VELIN } & \text { AIN } & \text { HWE } & \\ 10.79 & 110.33 & 9.43 & 126.15 & 495.37 & \end{array}$




\section{APPENDIX C:}

\section{BED-MATERIAL PARTICLE-SIZE DISTRIBUTION}




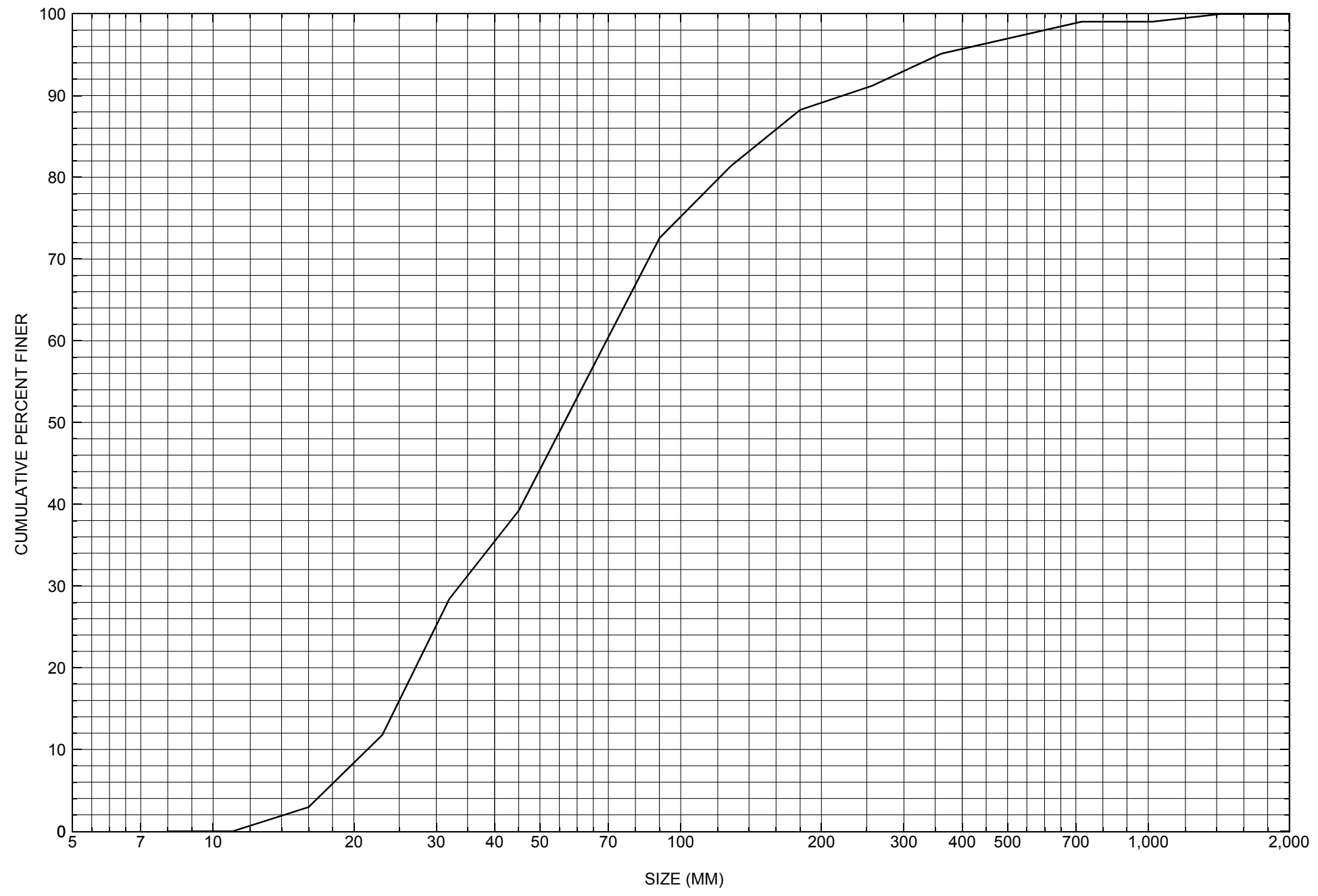

Appendix C. Bed material particle-size distribution for a pebble count in the channel approach of structure STOWTH00160039, in Stowe, Vermont. 


\section{APPENDIX D: \\ HISTORICAL DATA FORM}




\section{Structure Number STOWTH00160039}

\section{General Location Descriptive}

Data collected by (First Initial, Full last name) $\underline{\mathbf{L}}$. Medalie

Date $(M M / D D / Y Y) \_10 / 13 / \underline{95}$

Highway District Number (I - 2; nn) $\mathbf{0 6}$

Town (FIPS place code; I - 4; nnnnn) $\mathbf{7 0 5 2 5}$

Waterway ( $($ - 6) MOSS GLEN BROOK

Route Number C3016

Topographic Map Stowe

Latitude (I - 16; nnnn.n) $\mathbf{4 4 2 9 1}$
County (FIPS county code; I - 3; nnn)

Mile marker (I - 11; nnn.nnn) $\mathbf{0 0 0 0 0 0}$

Road Name (l - 7): MOSS GLEN FALLS RD

Vicinity (I - 9) 0.55 MI TO JCT W CL2 TH2

Hydrologic Unit Code: $\mathbf{0 2 0 1 0 0 0 5}$

Longitude (i - 17; nnnnn.n) $\mathbf{7 2 3 7 5}$

\section{Select Federal Inventory Codes}

FHWA Structure Number (I - 8) $\mathbf{1 0 0 8 0 8 0 0 3 9 0 8 0 8}$

Maintenance responsibility $(I-21 ; n n)$

Year built (I - 27; YYYY) 1982

Average daily traffic, ADT (I - 29; nnnnnn) 000100

Year of ADT (I - 30; YY) $\mathbf{9 3}$

Opening skew to Roadway $(I-34 ; n n)$

Operational status $(I-41 ; X) \quad \mathbf{A}$

Structure type (I - 43; nnn) $\mathbf{3 1 9}$

Approach span structure type $(I-44 ; n n n) \quad \mathbf{0 0 0}$

Number of spans (I - 45; nnn) $\mathbf{0 0 1}$

Number of approach spans (I - 46; nnnn) $\mathbf{0 0 0 0}$

Comments:

According to the structural inspection report dated 6/7/95, the structure is a corrugated galvanized plate pipe arch. The roadway over it is gravel surfaced with a sharp corner onto the RABUT side. The channel is scoured down to the bottom of the footing at the inlet on the LABUT side. The embankments are eroded US, with boulders showing. Small and minor gravel bars are noted. Debris is mostly minor at present. Stone fill is good at the arch ends, but partially slid into channel at the inlet on the right side, blocking $1 / 3$ of flow. The free poured concrete footing exposed near the outlet end on the right side is spalled with section loss plus a voided area at the very end. (Continued, page 32) 


\section{Bridge Hydrologic Data}

Is there hydrologic data available? $\underline{\mathbf{Y}}$ if No, type ctrl-n $h$

VTAOT Drainage area $\left(\mathrm{mi}^{2}\right)$ :

Terrain character:

Stream character \& type: -

Streambed material:

Discharge Data (cfs):

$$
\mathrm{Q}_{2.33} \frac{-}{\mathbf{9 9 0}}
$$

$\mathrm{Q}_{10} \frac{\mathbf{5 6 0}}{\mathrm{Q}_{100} \mathbf{1 1 9 0}}$

$\mathrm{Q}_{25} \lcm{\mathbf{8 2 0}}$

$Q_{500}$

Record flood date ( $M M / D D / Y Y)$ : I

Water surface elevation $(f t):-$

Estimated Discharge (cfs): Velocity at $\mathrm{Q}$ (ft/s):

Ice conditions (Heavy, Moderate, Light) : Debris (Heavy, Moderate, Light):

The stage increases to maximum highwater elevation (Rapidly, Not rapidly):

The stream response is (Flashy, Not flashy):

Describe any significant site conditions upstream or downstream that may influence the stream's stage: A report dated 12/29/82 mentions a rather large beaver dam just US of the site that has apparently caused a complete shift in the course of the stream, adding to the unstableness of the channel bed.

Watershed storage area (in percent):

The watershed storage area is: - (1-mainly at the headwaters; 2- uniformly distributed; 3-immediatly upstream oi the site)

Water Surface Elevation Estimates for Existing Structure:

\begin{tabular}{|l|l|l|l|l|l|}
\hline Peak discharge frequency & $Q_{2.33}$ & $Q_{10}$ & $Q_{25}$ & $Q_{50}$ & $Q_{100}$ \\
Water surface elevation (ft) $)$ & - & $\mathbf{5 . 5}$ & $\mathbf{6 . 7}$ & $\mathbf{7 . 8}$ & $\mathbf{9}$ \\
Velocity $(\mathrm{ft} / \mathrm{sec})$ & - & - & - & - & - \\
\hline
\end{tabular}

Long term stream bed changes: -

Is the roadway overtopped below the $\mathrm{Q}_{100}$ ? (Yes, No, Unknown): $\mathbf{U}$ Frequency: -

Relief Elevation $(f t)$ :

Discharge over roadway at $\mathrm{Q}_{100}\left(\mathrm{ft}^{3} / \mathrm{sec}\right)$ :

Are there other structures nearby? (Yes, No, Unknown): $\mathbf{U}$ Upstream distance (miles): Town: If No or Unknown, type ctrl-n os Highway No. : Structure No. : Year Built:

Clear span (ft): Clear Height (ft): Full Waterway $\left(f^{2}\right)$ : 
Downstream distance (miles): Town: Year Built:

Highway No. : Structure No. : Structure Type:

Clear span $(f t):$ Clear Height $(f t)$ : Full Waterway $\left(f^{2}\right)$ : -

Comments:

There are small areas of erosion at the inlet end of the arch. There is $4-5 \mathrm{ft}$ of cover over the pipe. The pipe has a slight reverse camber.

\section{USGS Watershed Data}

Watershed Hydrographic Data

Drainage area $(D A)$ $\mathrm{mi}^{2}$

Watershed storage (ST)

Bridge site elevation 820

Main channel length 4.23 $\%$

Lake/pond/swamp area $\mathrm{mi}^{2}$ $10 \%$ channel length elevation $\mathbf{9 5 0}$

Main channel slope $(S)$

(S) 457.05 $\mathrm{ft} / \mathrm{mi}$

Watershed Precipitation Data

Average site precipitation in

Average headwater precipitation in

Maximum 2yr-24hr precipitation event $(124,2)$ in

Average seasonal snowfall (Sn) $\mathrm{ft}$ 


\section{Bridge Plan Data}

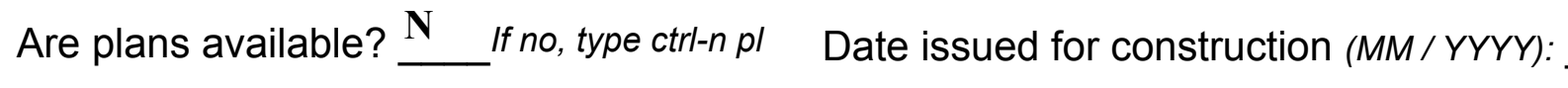

Project Number

Minimum channel bed elevation:

Low superstructure elevation: USLAB DSLAB USRAB DSRAB Benchmark location description:

NO BENCKMARK INFORMATION

Reference Point (MSL, Arbitrary, Other): Datum (NAD27, NAD83, Other):

Foundation Type: 4

If 1 : Footing Thickness

If 2: Pile Type:

If 3: Footing bottom elevation:

Is boring information available? $\mathbf{N}$

Foundation Material Type: $\mathbf{3}$

(1-Spreadfooting; 2-Pile; 3- Gravity; 4-Unknown)

Footing bottom elevation: -

Briefly describe material at foundation bottom elevation or around piles:

NO DRILL BORING INFORMATION

Comments:

$-$ 


\section{Cross-sectional Data}

Is cross-sectional data available? $\mathbf{N}$ If no, type ctrl-n xs

Source (FEMA, VTAOT, Other)? -

Comments: NO CROSS SECTIONAL INFORMATION

\begin{tabular}{|l|l|l|l|l|l|l|l|l|l|l|l|}
\hline Station & & - & - & - & - & - & - & - & - & - & - \\
\hline Feature & - & - & - & - & - & - & - & - & - & - & - \\
\hline $\begin{array}{l}\text { Low chord } \\
\text { elevation }\end{array}$ & - & - & - & - & - & - & - & - & - & - & - \\
\hline $\begin{array}{l}\text { Bed } \\
\text { elevation }\end{array}$ & - & - & - & - & - & - & - & - & - & - & - \\
\hline $\begin{array}{l}\text { Low chord- } \\
\text { bed }\end{array}$ & - & - & - & - & - & - & - & - & - & - & - \\
\hline Station & - & - & - & - & - & - & - & - & - & - & - \\
\hline Feature & - & - & - & - & - & - & - & - & - & - & - \\
\hline $\begin{array}{l}\text { Low chord } \\
\text { elevation }\end{array}$ & - & - & - & - & - & - & - & - & - & - & - \\
\hline $\begin{array}{l}\text { Bed } \\
\text { elevation }\end{array}$ & - & - & - & - & - & - & - & - & - & - & - \\
\hline $\begin{array}{l}\text { Low chord- } \\
\text { bed }\end{array}$ & - & - & - & - & - & - & - & - & - & - & - \\
\hline
\end{tabular}

Source (FEMA, VTAOT, Other)?

Comments: -

\begin{tabular}{|l|l|l|l|l|l|l|l|l|l|l|l|}
\hline Station & & - & - & - & - & - & - & - & - & - & - \\
\hline Feature & - & - & - & - & - & - & - & - & - & - & - \\
\hline $\begin{array}{l}\text { Low chord } \\
\text { elevation }\end{array}$ & - & - & - & - & - & - & - & - & - & - & - \\
\hline $\begin{array}{l}\text { Bed } \\
\text { elevation }\end{array}$ & - & - & - & - & - & - & - & - & - & - & - \\
\hline $\begin{array}{l}\text { Low chord- } \\
\text { bed }\end{array}$ & - & - & - & - & - & - & - & - & - & - & - \\
\hline Station & - & - & - & - & - & - & - & - & - & - & - \\
\hline Feature & - & - & - & - & - & - & - & - & - & - & - \\
\hline $\begin{array}{l}\text { Low chord } \\
\text { elevation }\end{array}$ & - & - & - & - & - & - & - & - & - & - & - \\
\hline $\begin{array}{l}\text { Bed } \\
\text { elevation }\end{array}$ & - & - & - & - & - & - & - & - & - & - & - \\
\hline $\begin{array}{l}\text { Low chord- } \\
\text { bed }\end{array}$ & - & - & - & - & - & - & - & - & - & - & - \\
\hline
\end{tabular}




\section{APPENDIX E: \\ LEVEL I DATA FORM}


U. S. Geological Survey

Bridge Field Data Collection and Processing Form

Qa/Qc Check by: $\underline{\mathbf{R B}}$ Date: $10 / 21 / 96$

\section{Structure Number}

STOWTH00160039

Computerized by: $\underline{\mathbf{R B}}$ Date: $10 / 22 / 96$

Reviewd by: MAI Date: 9/9/97

\section{A. General Location Descriptive}

1. Data collected by (First Initial, Full last name) R. HAMMOND

2. Highway District Number 06

Mile marker $\mathbf{0 0 0 0 0}$

County LAMOILLE (015)

Waterway (I - 6) MOSS GLEN BROOK

Route Number TH 16

Town STOWE (70525)

Road Name MOSS GLEN FALLS RD

Hydrologic Unit Code: $\mathbf{0 2 0 1 0 0 0 3}$

3. Descriptive comments:

Located 0.55 miles from the junction with CL2 TH2.

\section{B. Bridge Deck Observations}
4. Surface cover... LBUS 6
RBUS 6
LBDS 4
RBDS 6
Overall 6

(2b us,ds,lb,rb: 1- Urban; 2- Suburban; 3- Row crops; 4- Pasture; 5- Shrub- and brushland; 6- Forest; 7- Wetland)
5. Ambient water surface... US 1
UB 1
DS $\underline{2}$
(1- pool; 2- riffle)

6. Bridge structure type 3 (1- single span; 2- multiple span; 3- single arch; 4- multiple arch; 5-cylindrical culvert; 6- box culvert; or 7- other)
7. Bridge length 22
(feet)
Span length $\mathbf{2 1}$
(feet)
Bridge width $\underline{\mathbf{5 0 . 5}}$ (feet)

\section{Road approach to bridge:}
8. LB 2 RB 1
( 0 even, 1- lower, 2- higher)
9. LB_2
RB $\underline{2}$
(1-Paved, 2- Not paved)

10. Embankment slope (run / rise in feet / foot)

US left

US right

\begin{tabular}{|c|c|c|c|}
\hline \multicolumn{2}{|c|}{ Protection } & \multirow{2}{*}{ 13.Erosion } & 14.Severity \\
\hline 11.Type & 12.Cond. & $\mathbf{0}$ & - \\
\hline $\mathbf{2}$ & $\mathbf{1}$ & $\mathbf{0}$ & $\mathbf{2}$ \\
\hline $\mathbf{1}$ & $\mathbf{2}$ & $\mathbf{1}$ & $\mathbf{2}$ \\
\hline $\mathbf{2}$ & $\mathbf{2}$ & $\mathbf{1}$ & $\mathbf{2}$ \\
\hline $\mathbf{2}$ & $\mathbf{1}$ & $\mathbf{0}$ & - \\
\hline
\end{tabular}

Bank protection types: 0- none; 1- < 12 inches,

2- $<36$ inches; $3-<48$ inches;

4- < 60 inches; 5- wall / artificial levee

Bank protection conditions: 1- good; 2- slumped;

3- eroded; 4- failed

Erosion: 0 - none; 1- channel erosion; 2 -

road wash; 3- both; 4- other

Erosion Severity: 0 - none; 1- slight; 2- moderate; 3- severe

\section{Channel approach to bridge (BF):}

15. Angle of approach: $\mathbf{0}$

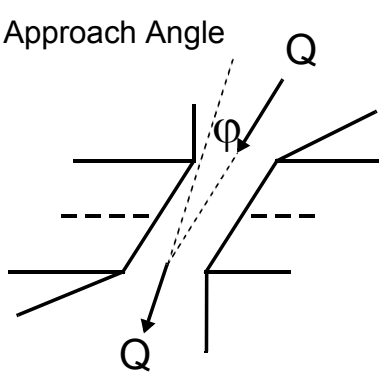

17. Channel impact zone 1 :

Where? $\underline{\mathbf{L B}}(L B, R B)$

Range? 5 feet US

Channel impact zone 2:

Where? LB $(L B, R B)$

Range? 8 feet $\underline{\mathbf{D S}}$

Impact Severity: 0- none to very slight; 1- Slight; 2- Moderate; 3- Severe
16. Bridge skew: $\mathbf{0}$ Bridge Skew Angle

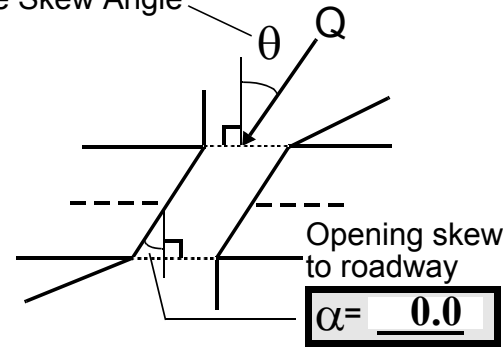

\section{Exist? $\mathbf{Y}(Y$ or $N)$}

Severity 2

(US, UB, DS) to $\underline{\mathbf{1 0}}$ feet $\underline{\mathbf{U S}}$

Exist? $\mathbf{Y}(Y$ or $N)$

Severity 2

$U B, D S)$ to $\underline{\mathbf{5 0}}$ feet $\underline{\mathbf{D S}}$ 
18. Bridge Type: $1 \mathbf{b}$

1a- Vertical abutments with wingwalls

$1 \mathrm{~b}$ - Vertical abutments without wingwalls

2- Vertical abutments and wingwalls, sloping embankment Wingwalls parallel to abut. face

3- Spill through abutments

4- Sloping embankment, vertical wingwalls and abutments

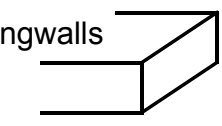

1a with wingwalls

Wingwall angle less than $90^{\circ}$.

19. Bridge Deck Comments (surface cover variations, measured bridge and span lengths, bridge type variations, approach overflow width, etc.)

4. The DS left bank is a lawn and the DS right bank is intersected by Moss Glenn Falls Road.

5. The upstream water surface is a series of small pools and riffles.

6. This is a multi-plate pipe arch set in concrete footings.

8. The road slopes gradually from the culvert in both directions.

15. The flow is straight from the approach cross section through the culvert to the exit section, but it bends just US and just DS of this straight section.

17. At high flows, water will impact both sides of the culvert opening. Also, a moderately severe third impact zone exists on the right bank from $120 \mathrm{ft}$ US to $90 \mathrm{ft}$ US.

\section{Upstream Channel Assessment}

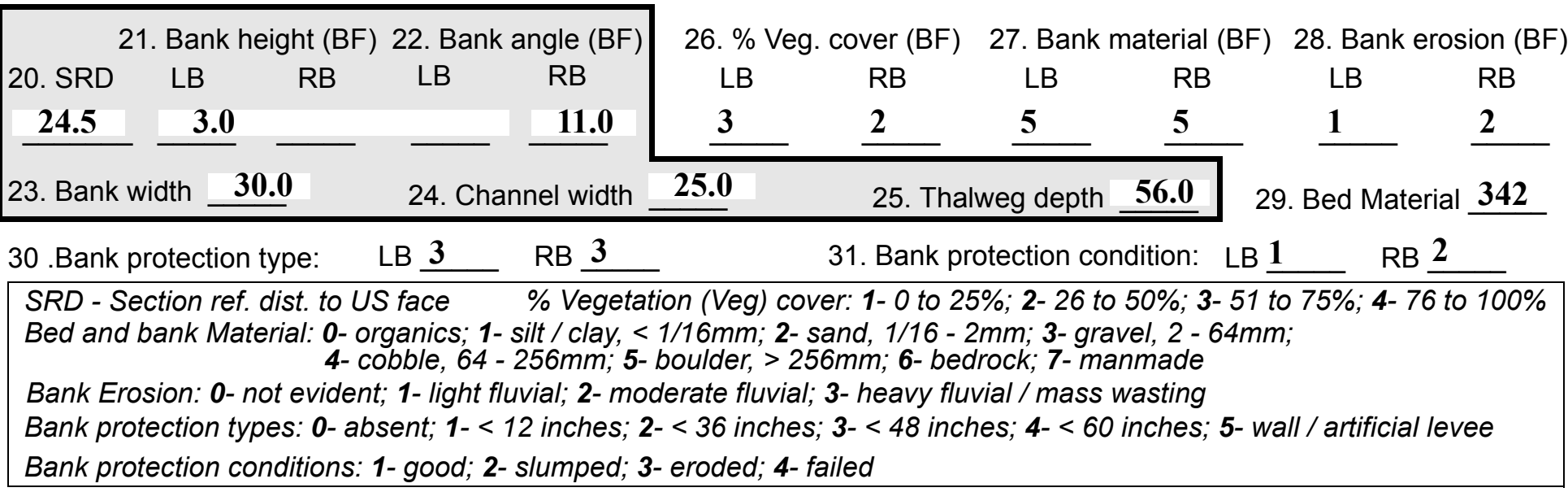

32. Comments (bank material variation, minor inflows, protection extent, etc.):

27. Both banks consist of large placed boulders and concrete blocks.

28. On the right bank, there is some mass wasting but it is not threatening to the road or culvert.

29. The sand in the bed fills the voids between the larger materials.

30. The left and right bank protection extends from the US bridge face to $100 \mathrm{ft}$ US.

31. On the right bank some of the protection is eroded and slumping. 
33.Point/Side bar present? Y

(Y or N. if $N$ type ctrl-n pb)34. Mid-bar distance: 12

35. Mid-bar width: $\mathbf{1 0}$

36. Point bar extent: 35 feet US

(US, UB) to $\underline{\mathbf{U B}}$ feet $\underline{50}$

(US, UB, DS) positioned $\underline{\mathbf{1 0}}$

$\%$ LB to $\underline{\mathbf{0}} \%$ RB

37. Material: $\mathbf{3 2 4}$

38. Point or side bar comments (Circle Point or Side; Note additional bars, material variation, status, etc.):

This point bar extends into the culvert.

39. Is a cut-bank present? $\mathbf{Y}$ ( $Y$ or if $N$ type ctrl-n $c b)$

41. Mid-bank distance: $\mathbf{5 0}$

42. Cut bank extent: 0

40. Where? $\underline{\mathbf{R B}}$ (LB or RB)

43. Bank damage: 2

(1- eroded and/or creep; 2- slip failure; 3- block failure)

44. Cut bank comments (eg. additional cut banks, protection condition, etc.):

This cut bank is a high water cut that is eroded with some slumping. Another very minor low water cut is on the left bank from $20 \mathrm{ft}$ to $30 \mathrm{ft}$ US.

45. Is channel scour present? $\mathbf{N}$ ( $Y$ or if $N$ type ctrl-n cs)

47. Scour dimensions: Length -

Width -

Depth : -

46. Mid-scour distance: -

48. Scour comments (eg. additional scour areas, local scouring process, etc.):

NO CHANNEL SCOUR

Some minor scour holes are behind boulders in the channel. The maximum scour depth is $1.5 \mathrm{ft}$.

49. Are there major confluences? $\mathbf{N}$

51. Confluence 1: Distance -

Confluence 2: Distance -

52. Enters on -

Enters on -

54. Confluence comments (eg. confluence name):

NO MAJOR CONFLUENCES
50. How many? -

53. Type(1- perennial; 2- ephemeral)

Type (1-perennial; 2- ephemeral) ( $(L B$ or $R B)$ (LB or $R B)$ 
65. Debris and Ice Is there debris accumulation?

$(Y$ or $N)$ 66. Where? $\underline{Y}$

(1- Upstream; 2- At bridge; 3- Both)

67. Debris Potential $\underline{3}$

( 1- Low; 2- Moderate; 3- High)

68. Capture Efficiency 3

(1-Low; 2- Moderate; 3- High)

69. Is there evidence of ice build-up? $\underline{3}$ (Y or $N)$

Ice Blockage Potential $\mathbf{N}$

(1-Low; 2- Moderate; 3- High)

70. Debris and Ice Comments:

1

There is a lot of debris on the large concrete blocks along the left bank US. There is also some small debris buried in the point bar inside the culvert.

\begin{tabular}{|l|c|c|c|c|c|c|c|c|}
\hline Abutments & $\begin{array}{c}\text { 71. Attack } \\
\angle \text { (BF) }\end{array}$ & $\begin{array}{c}\text { 72. Slope } \angle \\
\text { (Qmax) }\end{array}$ & $\begin{array}{c}\text { 73. Toe } \\
\text { loc. (BF) }\end{array}$ & $\begin{array}{c}\text { 74. Scour } \\
\text { Condition }\end{array}$ & $\begin{array}{c}75 . \text { Scour } \\
\text { depth }\end{array}$ & $\begin{array}{c}\text { 76. Exposure } \\
\text { depth }\end{array}$ & 77. Material & 78. Length \\
\hline LABUT & & $\mathbf{0}$ & $\mathbf{9 0}$ & $\mathbf{2}$ & $\mathbf{2}$ & $\mathbf{0 . 4}$ & $\mathbf{0 . 9}$ & $\mathbf{9 0 . 0}$ \\
\hline RABUT & $\mathbf{1}$ & $\mathbf{0}$ & $\mathbf{9 0}$ & & & $\mathbf{2}$ & $\mathbf{2}$ & $\mathbf{2 0 . 5}$ \\
\hline
\end{tabular}

Pushed: $L B$ or RB

Toe Location (Loc.): 0- even, 1- set back, 2- protrudes

Scour cond.: 0- not evident; 1- evident (comment); 2- footing exposed; 3-undermined footing; 4- piling exposed; 5- settled; 6- failed

Materials: 1- Concrete; 2- Stone masonry or drywall; 3- steel or metal; 4- wood

79. Abutment comments (eg. undermined penetration, unusual scour processes, debris, etc.):

0

1.6

1

74. The US end of the left abutment footing is exposed. The DS end of the right abutment footing is exposed. The spread base of the footing is undermined $0.4 \mathrm{ft}$ horizontally. Also, the DS end of the right abutment footing has broken off and is missing.

80. Wingwalls:

$\begin{array}{lllll} & & & & \\ \text { Exist? Material? } & \text { Scour } & \text { Scour } & \text { Exposure } & \text { Angle? Length? } \\ & \text { Condition? depth? } & \text { depth? } & & \end{array}$

USLWW:

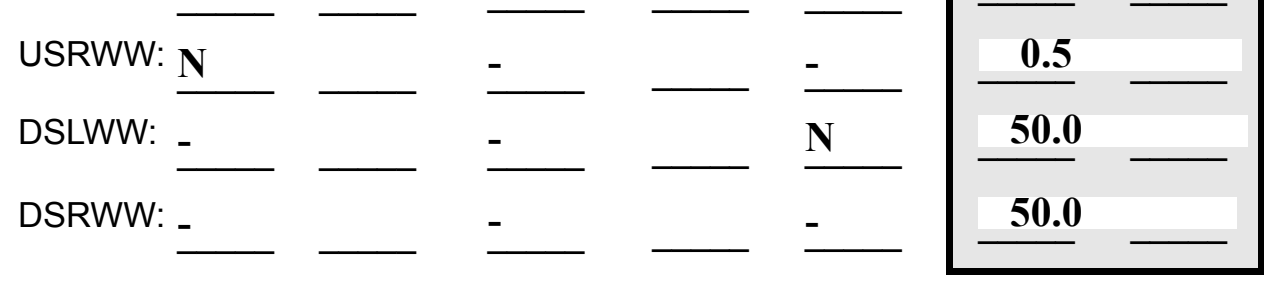

Wingwall materials: 1- Concrete; 2- Stone masonry or drywall; 3- steel or metal; 4- wood

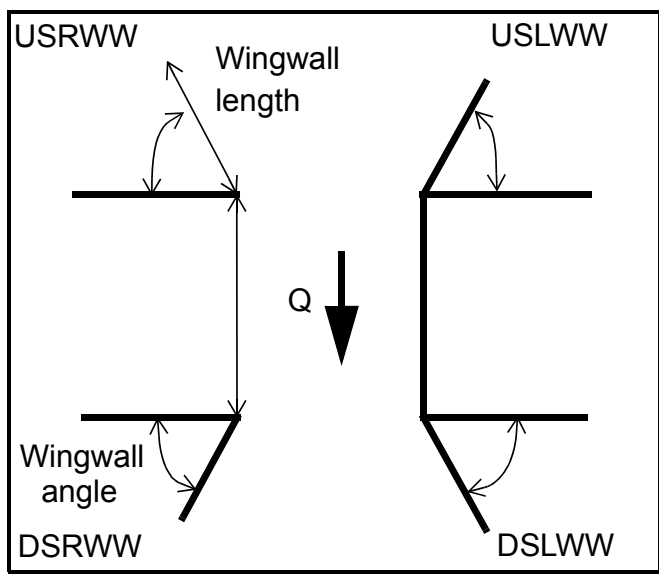

82. Bank / Bridge Protection:

\begin{tabular}{|l|l|l|l|l|l|l|l|c|}
\hline Location & USLWW & USRWW & LABUT & RABUT & LB & RB & DSLWW & DSRWW \\
\hline Type & - & - & $\mathbf{N}$ & - & - & - & $\mathbf{1}$ & $\mathbf{1}$ \\
\hline Condition & $\mathbf{N}$ & - & - & - & - & - & $\mathbf{4}$ & $\mathbf{4}$ \\
\hline Extent & - & - & - & - & - & $\mathbf{3}$ & $\mathbf{3}$ & - \\
\hline
\end{tabular}

Bank / Bridge protection types: 0- absent; 1- < 12 inches; 2- < 36 inches; 3- < 48 inches; 4- < 60 inches; 
83. Wingwall and protection comments (eg. undermined penetration, unusual scour processes, etc.):

-
-
-
-
-
-
-
-
-

\section{Piers:}

84. Are there piers? 82. (Y or if $N$ type ctrl-n pr)

\begin{tabular}{|l|l|l|l|l|l|l|l|}
\hline \multirow{2}{*}{$\begin{array}{l}85 . \\
\text { Pier no. }\end{array}$} & \multicolumn{3}{|c|}{ width (w) feet } & \multicolumn{3}{c|}{ elevation (e) feet } \\
\cline { 2 - 9 } & w1 & w2 & w3 & e@w1 & e@w2 & e@w3 \\
\hline Pier 1 & - & - & - & - & - & - \\
\hline Pier 2 & - & - & - & - & - & - \\
\hline Pier 3 & - & - & - & - & - & - & - \\
\hline Pier 4 & - & - & - & - & - & w1 \\
\hline
\end{tabular}

\begin{tabular}{|l|l|l|l|l|}
\hline Level 1 Pier Descr. & \multicolumn{1}{|c|}{1} & \multicolumn{1}{|c|}{2} & 3 & \multicolumn{1}{|c|}{} \\
\hline 86. Location (BF) & The & and DS & & - \\
\hline 87. Type & left & ends & & - \\
\hline 88. Material & and & of & & - \\
\hline 89. Shape & right & the & & - \\
\hline 90. Inclined? & abut & abut & & - \\
\hline 91. Attack $\angle$ (BF) & ment & ment & N & - \\
\hline 92. Pushed & pro- & s. & - & - \\
\hline 93. Length (feet) & - & - & - & - \\
\hline 94. \# of piles & tec- & & - & - \\
\hline 95. Cross-members & tion & & - & - \\
\hline 96. Scour Condition & is at & & - & - \\
\hline 97. Scour depth & the & & - & - \\
\hline 98. Exposure depth & US & & - & - \\
\hline
\end{tabular}

LFP, LTB, LB, MCL, MCM, MCR, RB, RTB, RFP

1- Solid pier, 2- column, 3- bent

1-Wood; 2- concrete; 3- metal; 4- stone

1- Round; 2- Square; 3- Pointed

Y-yes; $N-$ no

$L B$ or $R B$

0- none; 1- laterals; 2- diagonals; 3- both

0- not evident; 1- evident (comment);

2- footing exposed; 3- piling exposed;

4- undermined footing; 5- settled; 6- failed 
99. Pier comments (eg. undermined penetration, protection and protection extent, unusual scour processes, etc.):

-
-
-
-
-
-
-
-
-
-

100.

\section{E. Downstream Channel Assessment}

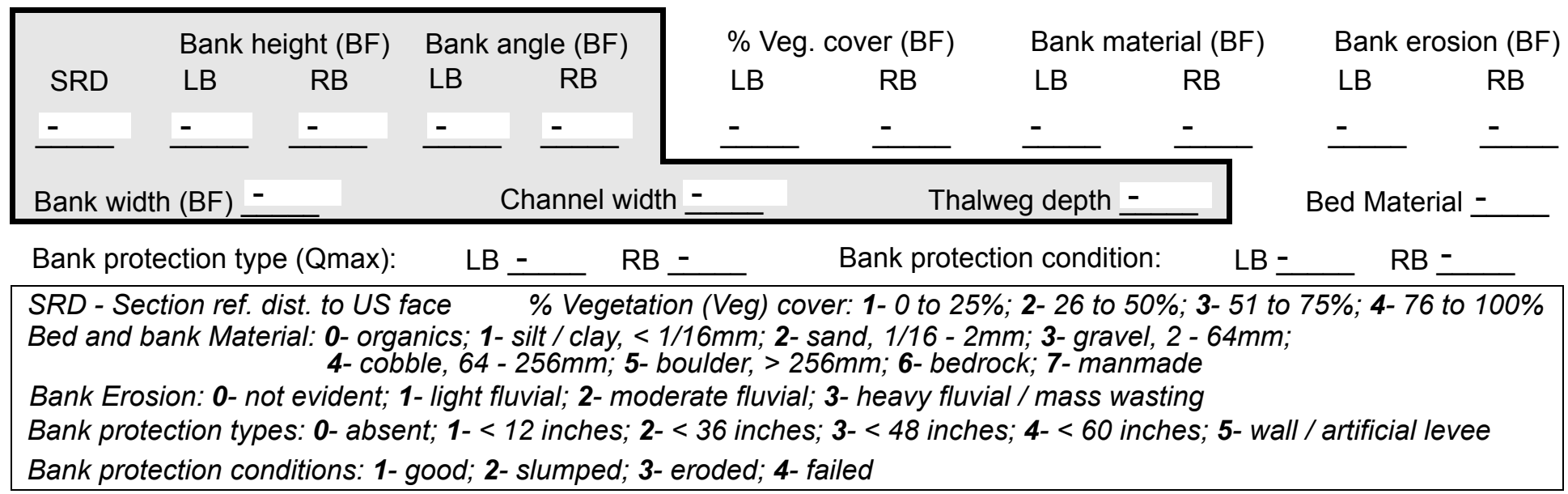

Comments (eg. bank material variation, minor inflows, protection extent, etc.):

-
-
-
-
-
-
-
-

NO PIERS

101. Is a drop structure present? ( $Y$ or $N$, if $N$ type ctrl-n ds)

102. Distance: $\mathbf{2 3 . 5}$ feet
103. Drop: $\mathbf{5 . 0}$ feet
104. Structure material:
(1- steel sheet pile; 2- wood pile; 3- concrete; 4- other)

105. Drop structure comments (eg. downstream scour depth): 
Point bar extent: $\underline{\mathbf{3}}$ feet $\underline{\mathbf{3}}$ (US, UB, DS) to $\underline{\mathbf{1}}$ feet $\underline{\mathbf{2}}$ (US, UB, DS) positioned $\underline{\mathbf{T h}} \%$ LB to $\underline{\mathbf{e}} \%$ RB Material: rig

Point or side bar comments (Circle Point or Side; note additional bars, material variation, status, etc.):

ht and left bank protection extends from the DS bridge face to $100 \mathrm{ft}$ DS. On the right bank the protection is eroded and is slumping near the end of the culvert.

Is a cut-bank present?

Cut bank extent: feet ( $Y$ or if $N$ type ctrl-n cb) Where? (LB or $R B)$ feet (US, UB, DS)

Bank damage: (US, UB, DS) to (1- eroded and/or creep; 2- slip failure; 3- block failure)

Cut bank comments (eg. additional cut banks, protection condition, etc.):

$\mathbf{N}$

Is channel scour present? ( $Y$ or if $N$ type ctrl-n cs)

Mid-scour distance: $\mathbf{N O}$ $\mathbf{0}$ Scour comments (eg. additional scour areas, local scouring process, etc.):

Are there major confluences?

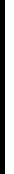
( $Y$ or if $N$ type ctrl-n $m c)$ Enters on $\underline{\mathbf{0}}(L B$ or $R B)$
Enters on $\underline{\mathbf{U B}}(L B$ or $R B)$ Confluence comments (eg. confluence name):

DS

\section{F. Geomorphic Channel Assessment}

1- Constructed

2- Stable

3- Aggraded

4- Degraded

5- Laterally unstable 6- Vertically and laterally unstable
How many?

Type 11 (1- perennial; 2- ephemeral) Type 20 (1- perennial; 2- ephemeral) Mid-bank distance: 
108. Evolution comments (Channel evolution not considering bridge effects; See HEC-20, Figure 1 for geomorphic descriptors):

342

$-$

Y

LB

20

10

DS

40

DS

1 


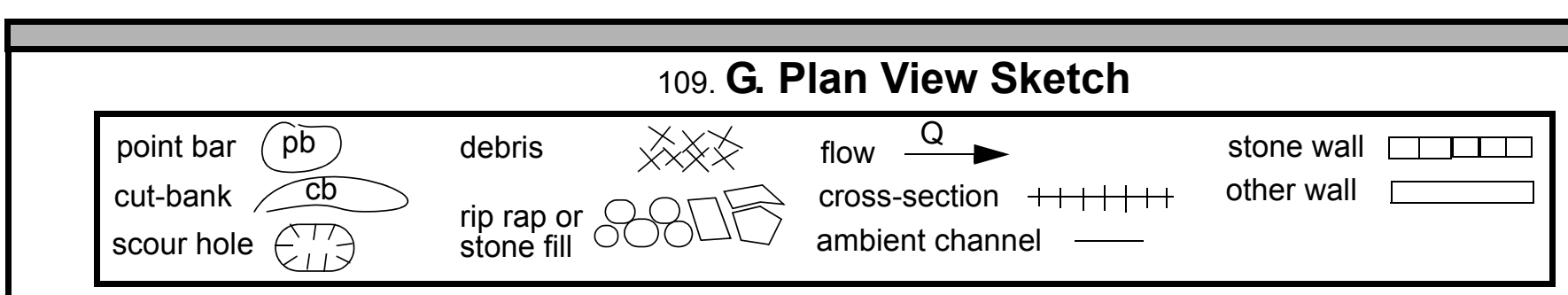


APPENDIX F:

SCOUR COMPUTATIONS 


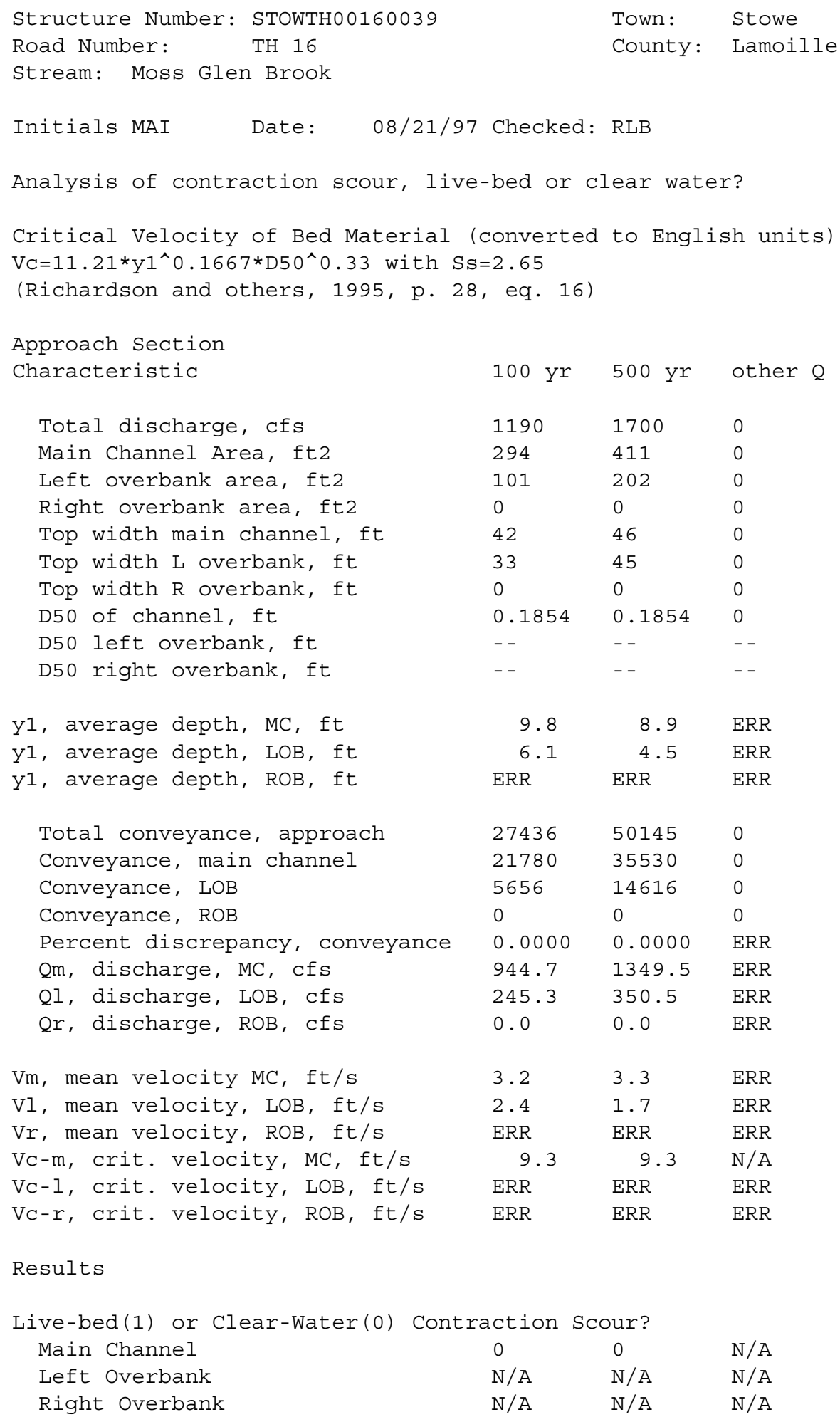


Clear Water Contraction Scour in MAIN CHANNEL

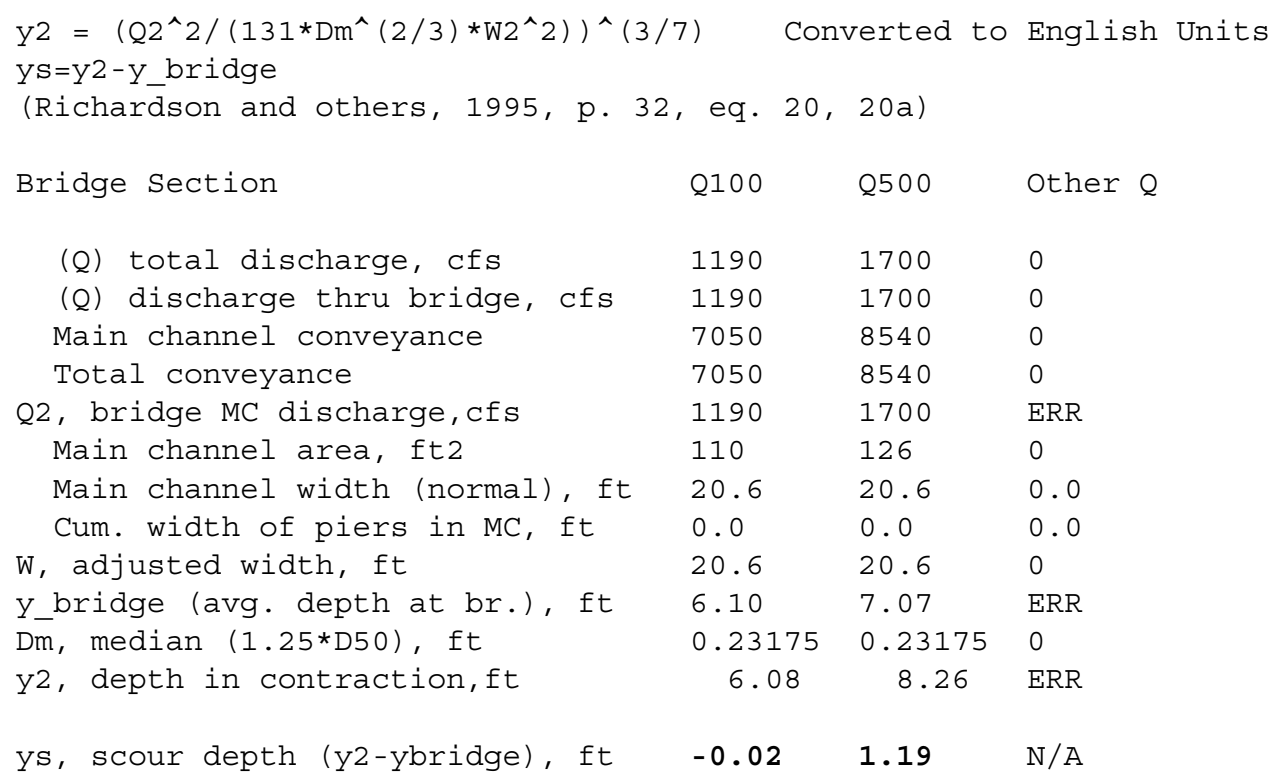

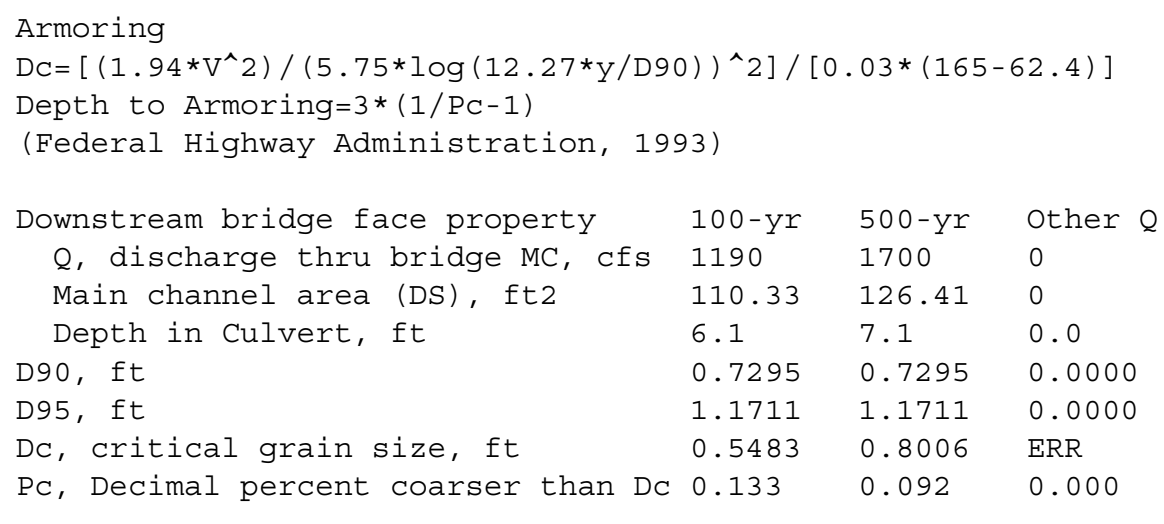

$\begin{array}{llll}\text { Depth to armoring, ft } & 10.76 & 23.65 & \mathrm{~N} / \mathrm{A}\end{array}$

Abutment Scour

Froehlich's Abutment Scour

$\mathrm{Ys} / \mathrm{Y} 1=2.27 * \mathrm{~K} 1 * \mathrm{~K} 2 *\left(\mathrm{a}^{\prime} / \mathrm{Y} 1\right)^{\wedge} 0.43 * \mathrm{Fr} 1^{\wedge} 0.61+1$

(Richardson and others, 1995, p. 48, eq. 28)

Characteristic

Left Abutment Right Abutment

$100 \mathrm{yr} Q 500 \mathrm{yr} Q$ Other Q 100 yr Q 500 yr Q Other Q 


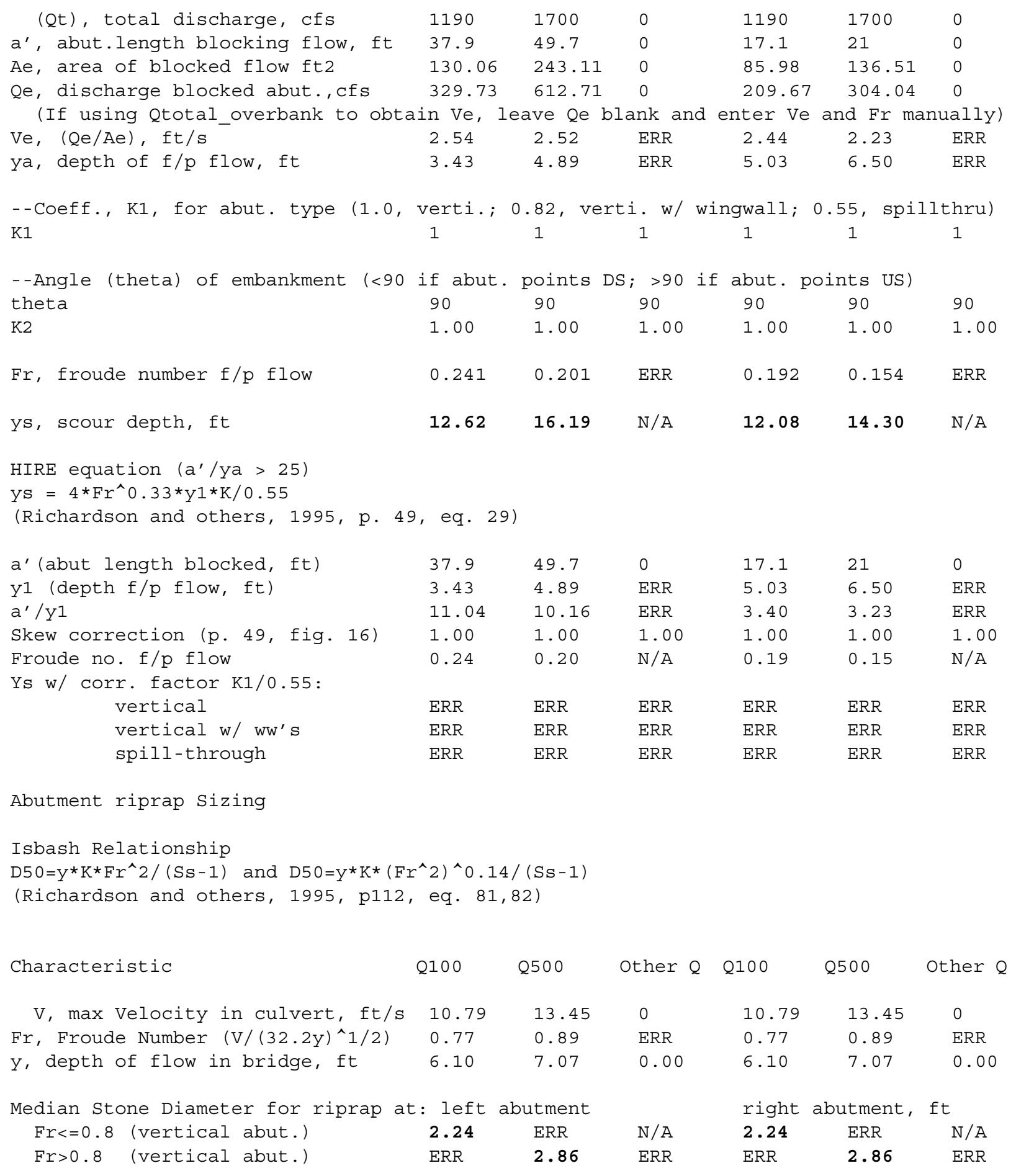


